\title{
Fra tiden mellem krigene.
}

Af Holger Hjelholt.

1.

\section{En tildragelse fra sprogreskriptets indforelse.}

Den sprogordning, som indførtes i Mellemslesvig, efter at Danmark ved Istedslaget igen var bleven herre i Sønderjylland, stødte som bekendt på meget stor uvilje og megen modstand hos den ganske overvejende del af den mellemslesvigske befolkning. For de enkelte bestemmelser i sprogordningen har jeg gjort rede i min bog »Den danske sprogordning $i$ Slesvig mellem krigene« (1923), og til denne må jeg have lov at henvise som baggrund for dette som for de følgende par småstykker. Hovedpunkterne for den mellemslesvigske sprogordning var indforelsen af dansk som skolesprog og af dansk og tysk som afvekslende kirkesprog. Begge dele havde før været udelukkende tysk. Den nye ordning blev truffet ved reskripter fra regeringskommissæren F. F. Tillis c h den 7. og 8. februar og den 4. marts 1851. For landsognene i Flensborg provsti indførtes ordningen ved reskriptet 7. februar.

Sprogreskripternes egentlige ophavsmand var, som jeg også i min bog har gjort rede for, ikke regeringskommissæren Tillisch, men hans medhjælper, den unge sønderjyde Th. A. .J. Reg e n burg. Tillisch havde i 1849 taget Regenburg med til Flensborg som sin privatsekretær, og 1 . september 1850 var Regenburg stillet i spidsen for kirke-, skole- og undervisningsvæsenet $i$. departement under regerings- 
kommissæren. Sprogreskripterne fremkaldte en sand flom af andragender fra de mellemslesvigske sogne om at blive befriede for dansk som officielt sprog, og endvidere måtte Regenburg i sit kontor i Flensborg modtage talrige personlige henvendelser fra de utilfredse mellemslesvigere. $O m$ en sådan henvendelse er det, der $\mathrm{i}$ det følgende skal berettes. Beretningen er givet af Heinrich Chr. P. Wöldike, der i 1851 fungerede som bureauchef under regeringskommissæren og i 1852 blev medlem af appellationsretten i Flensborg. Ved brev af 30 . december 1855 oversendte Wöldike efter Regenburgs anmodning denne sin beretning. Regenburgs anmodning er sikkert fremkaldt ved ønsket om netop på et tidspunkt, der var kritisk for sprogordningens opretholdelse, at sidde inde med så meget stof som muligt til forsvar for denne, og hertil må beretningen formentlig også siges at være ret godt egnet. Krisen for sprogordningen skyldtes den daværende slesvigske minister H. J. A. Raasløff, der imidlertid i februar 1856 trådte ud af ministeriet.

Efter disse par indledende bemærkninger skaI jeg nu gengive Wöldikes bekræftede fremstilling af tildragelsen:

"Nogen tid efter at der var bleven truffet foranstaltninger til indforelsen af det danske sprog som skole- og kirkesprog i Flensborg provsti, indfandt sig en dag to mænd på mit comptoir, af hvilke den ene, da de vare kommet ind af doren, tog et sammenfoilet papir op af lommen. Da jeg bemærkede dette, gjorde jeg nuværende etatsråd Regenburg, der dengang arbeidede i samme værelse med mig, opmærksom på disse folk, idet det ikke var første gang, at folk i den tid var kommet ind på comptoiret på lig- 
nende måde, og da altid på mit spørgsmål, hvem de vilde tale med, havde onsket at ville tale med herr Regenburg. Regenburg gik derpå hen til disse folk, og begyndte der nu følgende samtale - Regenburg. Vil de tale med mig? Mændene. Ja. R. Hvad ønske de da? M. Vi vilde gjerne bede om at blive fri for sproget. - R. Fra hvilket sogn ere de? - M. Vi ere fra Grundtoft sogn. R. Hvem har sendt dem hertil? - M. Hele sognet. De ville alle gjerne være fri for sproget. - R. For sproget? Mene de måskee det danske sprog? - M. Ja. - R. Hvorfor vil de da af med det danske sprog? M. Ja vi kan ikke forståe dansk, og derfor kan vi ikke mere gåe i kirke, og børnene kan ikke lære noget, når de skal læres på dansk. R. Ere de også virkelig viss på, at det forholder sig således? M. Ja det er ganske vist. R. Ja men jeg er dog også temmelig nøie bekjendt med forholdene i Grunitoft og nærmeste omegn, og det forekommer mig dog, som om folkene der både forståe og tale dansk. M. Ja vi kan nok tale sådan lidt dansk, men det er ikke rigtig dansk, vi forståe ikke kjøbenhavnsk dansk, og præsten forstår heller ikke vort sprog. R. Fre de vis på det? Jeg troer virkelig, de tage feil. Husk dog på, at jeg i dette øieblik taler reent dansk med dem, og at de ligeså godt forståe mig som jeg forståer dem; vil de virkelig endnu sige, at de ikke forståe dansk. M. W'ie beliebt? R. Jeg siger, forståe de virkelig ikke dansk? M. Wie meinen Sie? $R$. Må jeg nu bede dem om, at de øieblikkeligen forlade comptoiret og ikke oftere komme med sådanne historier, dem ganske ubevidst tale de dansk med mig hele tiden og fra det samme øieblik af, at jeg gjør dem opmærksom på; at de tale dansk, vil de på engang ikke længere kunne forståe det. Det seer næ- 
sten ud, som om de vilde have mig til bedste. - Herpå forlode mændene comptoiret«.

Det sammenfoldede papir, som det i beretningen nævnes, at mændene straks ved deres ankomst tog op af lommen, var ganske sikkert en sprogpetition, et af de næunte mange andragender om at blive fri for »sproget«, for at bruge mændenes udtryk. Et sådant andragende fra Grundtoft (Grumtoft) sogn findes i slesvigsk ministeriums arkiv dateret den 10. marts, og det er formentlig dette, som mændene bragte med sig. Det bærer omkring halvtrediehundrede underskrifter. I andragendet som i beretningen er hovedtonen den for os danske så dybt tragiske fornægtelse fra mellemslesvigernes side af deres eget gode danske modersmål. Det indrommes vel, hedder det i andragendet, at man i sognet hører folk indbyrdes tale i en dansk dialekt, men selv om man forstår denne, forstår man aldeles ikke en dansk prædiken og end mindre en pradiken holdt på københavnerransk. Det derværende dansk er blandet med tysk og har ingen ord for højere begreber. Endelig hævdes det, at selve denne, fra det virkelige danske helt forskellige danske dialekt ikke er almindelig i den daglige omgang, at sproget i familierne (familiesproget?) er tysk, og at forældrene til deres børn kun taler tysk. Dette sidste forhold var det jo, der beseglede det danske sprogs dødsdom i de fleste sogne $i$ Angel.

\section{2.}

\section{Studentersangerne i Slesvig by og i Hütten bjerge.}

I årene umiddelbart før 1864, da uvejret brød ind over den danske helstat, var det, som om man både 
på dansk og på tysk side følte en uimodståelig trang til at holde hærskue over de trofaste tropper. Dette skete ved de mange danske og tyske fester, der $\mathbf{i}$ disse år foranstaltedes. Af danske fester er de bekendteste vel nok slesvigernes besøg i København i året 1861 og "løvefesten« i Flensborg det følgende år ved afsløringen af Bissens monument på Flensborg kirkegård over Isteddagens faldne. Betegnende for indtrykket af den første fest er en udtalelse af pastor Chr. Ewaldsen i Flensborg $i$ et brev kort efter. "Det eneste nye her", skriver han, "er begeistringen over reisen, der er æmnet for alle samtaler: det er dog noget af det glædeligste, der er skeet her i Slesvig .... «1). Af tyske fester skal jeg fra året 1862 lige nævne to, hvoraf den ene fandt sted kort før løvefesten, den anden kort efter. Den første var den i Rendsborg den 13. og 14. juli afholdte første turnerfest for hertugdømmerne Slesvig, Holsten og Lauenborg, den anden sangerfesten i Husum den 27. juli. Fra dansk side betegnede man de toner, der lød ved begge disse fester, som både slesvig-holstenske og oprørske, og de fremkaldte også bagefter retslig indskriden fra regeringen. Omvendt var det ejderdanske strenge, der ansloges ved løvefesten, hvor der taltes om, at kongeriget og Slesvig burde forenes ved samme friheder. Varslerne om helstatspolitikkens endelige skibbrud var tydelige nok. Man stod på tærsklen af den danskslesvigske fællesforfatning, og støttet til Tyskland rejste slesvig-holstenerne hovederne som i årene før 1848. Angelboernes overmod voksede bestandig, som let hed i et brev fra en af de angelske præster, der til daglig havde at kæmpe med befolkningens modstand mod den danske sprogordning. $\left.{ }^{2}\right)$

1) Chr. Ewaldsen $1 / 8$ til Repenburg. (Rigsarkivet).

$\left.{ }^{2}\right)$ Im. Barfod ${ }^{10 / 8} 1862$ til Regenburg. (Rigsarkivet). 
Men alt var nu ikke som i Angel, selv ikke i det sydligste Slesvig. Et vidnesbyrd om en noget anden stemning overfor konge og stat har man fra det besøg, som de halvthundrede københavnske studentersangere, der skulde deltage i festen i Flensborg den 25. juli, i-dagene forud aflagde i Slesvig by og i Hütten bjerge. Om dette besøg er det, at de folgende linjer $\mathrm{i}$ det væsentlige skal handle.

Initiativet til dette besøg blev naturligt nok taget af de $i$ Slesvig by bosatte danske embedsmænd. Den overvejende del af Slesvig bys indfodte befolkning var tysksindet. I den iøvrigt i flere henseender fejlagtige skildring af besøget hos Axel Sørensen: studentersangforeningen 1839-1889 (1889) hedder det herom, at næppe var det i Slesvig rygtedes, at studentersangerne skulde assistere ved løvefesten, „før der indlob en hjertelig og i høj grad lokkende indbydelse, unclertegnet af gamle studentervenner og sangere (Joh. Helms, dengang kcllaborator ved domskolen, dr. Tryde, tidligere medlem af oktetten, og nuvarende borgmester Knudsen $\left.{ }^{1}\right)$ ) om at gæste Slesvig by $i$ dagene umiddelbart før festen«. Af studentersangforeningens noget mangelfulde arkiv fremgår det, at der den 2ii. juni er sendt en rundskrivelse fra bestyrelsen til samtlige medlemmer angăende en tur til Slesvig og Flensiorg i juli måned.") Den 28. juni skriver formanden overlærer, cand. theol. O. J. C. Ottesen herom til rektoren ved domskolen i Slesvig, S. Povelsen, der omgâende meddeler, at han vil sam. mentromme komiteens fem medlemmer, "for at vi samlede kunne udfardige bevidste officielle indby-

1) II. A. V. Knulsen, lengang herredsfoged i Treia og Arns herreter og hosat i slesvig.

foreningen. 
delse«. "Modtag foreløbig herved min forsikring om, hvor kjært det er mig og, jeg troer at turde sige, alle hernede, at der altså er udsigt til, at studentersangforeningens besøg i Slesvig by bliver til virkelighed«. Den omtalte officielle indbydelse modtoges af sangforeningen den 2 . juli.

Blandt de studentersangere, der kom med på turen, var Laurids Skaus søn Peter Lauridsen S. I et brev til faderen af 9 . juli ${ }^{1}$ ) fortæller han, at den hele tur - til Slesvig og til Flensborg - vil vare fra den 21. til den 27. juli, og at han selv har været så heldig at kunne komme med. "Det var ordnet således, at af de tegnede 75 skulde bestyrelsen ( 3 mand) forlods, dernæst af bestyrelsen vælges 20 af alle stemmer og endelig 27 trække lod. Disse fordeltes så efter stemmerne, og for min stemme kunde 5 komme med af 13. Og jeg havde så det held at komme med på det fjerde lod. Der er noget i høi grad hidsende ved en sådan lodtrækning, at høre det ene navn efter det andet og et tilsvarende glædesudbrud, kun ikke sit eget. Men mit kom jo da også, og jeg gav et glædeshyl og blev misundt. Thorvald Paulsen var valgt af bestyrelsen. Denne tour bliver jo arrangeret billigt, og vi har desuden, jeg tror 50 rdlr. i kassen, der anvendes dertil. Derfor vil touren koste 5 rdlr. tour og retour og 3 rdlr. tour alene. Når så dertil lagges 3 rdlr., vil det hele jo blive overmăde billigt i forhold «. Han hábede, at han ikke skulde behøve at ty til faderen om hjælp. skulde det knibe, syntes det ham imidlertid billigt, at faderen hjalp ham, da det sandsynligvis blev hans hele sommerferie. Hvilken vej, man vilde vælge til Slesvig, var endnu ikke bestemt. "Der har været tale om at komme i land et sted på

1) Brevet findes i Laurids Skaus papirer. (Kgl. bibl.) 
kysten, og der har været tale om at gå over Kiel, Neumünster og Rendsborg. Det sidste synes mig en blandet forngielse. Man vilde da være nødt til at sætte sig i forbindelse med militæret, synes mig. Men hvordan det så end går, kommer vi jo nok dertil. Jeg håber rigtignok udenom disse røverreder». Som svar på dette brev afsendte Laurids Skau, der ikke var smålig og gerne så sønnen deltage i noget, som kunde have politisk betydning, omgående 15 rdlr. til København.')

Peter Skaus ønske om at undgå "røverrederne« Kiel, Neumünster og Rendsborg gik ikke i opfyldelse. Den 21. juli rejste studentersangerne pr. skib til Kiel, hvortil de efter en noget besværlig sørejse ankom den følgende formiddag. ${ }^{2}$ ) Nogen slesvig-holstenske demonstrationer fandt dog ikke sted i Kiel, bortset fra den på den tid så yndede farvesammenstilling af rodt, hvidt og blåt. 3 uskyldige unge mennesker, hedder det $\mathrm{i}$ "Fædrelandet«s beretning, opstillede sig ved studenternes afrejse fra Kiel på banegården, den ene med en rød, den anden med en hvid og den tredje med

1) Dette har han noteret på sønnens brev.

$\left.{ }^{2}\right)$ In udforlig beretning om studentersangernes rejse findes i "Fædrelandet". Den stammel" sikkert fia Carl Ploug, der var med pá turen. I brev af 2 . august til $L$. Skau (kgl. bibl.) fra davarende herredsfoged i Satrup og Mårkæx r herreder H. R. Hiort Lorenzen (bosat i Slesvig) hedder det også, at Ploug selv har refereret til Fædrelandet. Hiort Lorenzen giver iovrigt selv i sit navnte brev et udforligt referat af festlighederne i Slesvig by og af de herfra foretagne udflugter. Han havde to studentersangere indkvarterede hos sig og var med ved de forskellige fester. Pd́ Fardrelandets og Hiort Lorenzens referater samt et enkelt sted på Flensburger Zeitungs bygger jeg i hovedsagen min folgende skildring. Det vil af denne fremgå, at man ikke tør stole på fremstillingen hos Axel Sørensen og heller ikke på de erindringer, som i Gransevagten. Maj 1929 i E. J. C. Rambusch: Minder fra Sydslesvig $1857-63$ (S. $154 \mathrm{f}$ ) findes herom. Pả de urigtigheder, som findes $\mathrm{i}$ disse to skildringer, skal jeg ikke komme ind, da de let vil fremgå ved en sammenligning. 
en blå hue.') Over Neumünster, hvor stemningen fra befolkningens side ikke var bedre, gik rejsen til Rendsborg, hvor sangerne blev modtagne med jubel af den derværende danske garnison. Til Slesvig ankom man en del senere end oprindelig bestemt, og programmet kunde derfor ikke helt overholdes. Et påtænkt besøg samme dag i domkirken måtte opgives, og også koncerten hen på eftermiddagen i rådhussalen måtte indskrænkes noget. Her i rådhussalen, den gamle stændersal, hvor det i 1842 var bleven forbudt Peter Hiort Lorenzen at tale dansk, lød nu Københavnerstudenternes sange. Det var, skriver Hjort Lorenzen, den smukkeste musik, der nogensinde har været hort i Slesvig. Udenfor programmet blev en af Carl Ploug til lejligheden skreven sang omdelt og sunget:

"Land, som har adlydt farlenes love

Varnet af Thyra, varget af Knud!

Folk, som har fulgt os vidt over vove, Hver gang pá vikingefarrd vi drog ud«.

Efter koncerten gik man ned til Slien og blev i både satte over til Haddeby. Her sang studentersangerne fra den gamle kirkes kor H. P. Holsts gribende sang: Slumrer sødt i Slesvigs jord. Ude på kirkegården ved oberst Magius' grav og gravene for (le andre i Påskeslaget faldne danske gentoges sangens sidste vers: "Skøn er døden, som I fik«, med dets lofte, at "hvor danske toner klinge, - skal med stolthed store, små - fædrelandets tak jer bringe».

Den følgende dag var viet en udflugt til Dannevirke, hvortil der kørtes i vogne, "der efter eget tilbud var stillede af bønderne i Lille Dannevirke,

1) Fadrelandet ${ }^{25} / 71862$ (nr. 170). 
Husby, Skovby, Selk og Bustorf sogne og kjørte af dem selv«. ${ }^{1}$ ) I „Fædrelandet«s referat hedder det endvidere om festen ved middagstid på Thyraborg, hvor der veksledes med taler, sange og en improviseret gøglerforestilling som parodi på en turnerfest: "Havde bønderne været lidt tause på vognene, fordi de havde ondt ved at forståe os og vi dem, så var det tydeligt at see, at de vare rigtig fornøiede under festen. Jeg havde det held at komme til at tale med et par af dem, og det var så sundt og forstandigt, hvad de sagde om de politiske forhold, at jeg overraskedes derved. At Eideren er Danmarks grændse, og de selv tydsktalende danske, vidste de meget godt; det eneste, de vare utilfredse med, var, at de ikke nød samme friheder og rettigheder som deres ligemænd i kongeriget.... Dagen sluttedes med en fest og et bal på Stampemøllen, hvor dansen gik særdeles livlig til kl. 2 .

Om morgenen den 24. juli var det, at turen gik til de skønne Hütten bjerge. I både sattes der over til færgestedet Fahrdorf, hvor der var mødt omkring 30 vogne fra byerne Hütten, Ascheffel, Breckendorf, Hummelfeld og enkelte også fra Treia. Bønderne kørte så sangerne og deres værter til Ascheffel. »Overalt, hvor vi kom frem, besvarede befolkningen venlig vore hilsener; ved Geltorf skole stod hele ungdommen, drenge og piger sammen, udenfor og råbte hurra; men i Ascheffel selv stod de unge piger på gaden med kurve fulde af bouquetter, hvormed de overøste os. Disse bouquetter havde den særegenhed for os, at de forenede det nyttige med det behagelige, uden at der dog var tænkt på det første. Herovre anvender man nemlig ribsgrene på samme

1) Fædrelandet ${ }^{25}, 71862$ (nr. 170). 
måde, som vi bruge rønnebær om efteråret, i bouquetter og til decoration; men de modne ribs vare en særdeles velkommen tilgift for os af veiens støv torstige studenter; vi løste bouquetterne op, spiste ribsene og fæstede roserne og studenternellikerne $i$ vore knaphuller«. Fra Ascheffel gik det i et langt tog med musik i spidsen op på Aschberg, hvor Dannebrog vajede, og selvfølgelig dvæles der i referatet i "Fædrelandet« ved den smukke udsigt fra bjerget: et stykke af Sliens blarike, bugtende strøm i nord, i øst Eckernførde og fjorden, mod syd Rendsborgs tårne og mod vest Krop og den flade højderyg. "På bjerget samledes flere og flere bønder .... og dels ved samtale ned dem, dels med nationalsange gik en timestid deroppe«. Bl. a. sang man Der er et yndigt land og Danmark dejligst vang og vænge. ${ }^{1}$ ) Derefter gik det tilbage til krohaven, hvor frokosten indtoges, og her udtalte herredsfogden i Hütten herred $M$. Blaunfeldt, der præsiderede, bl. a., "at i Hütten herred kjendte man kun een farve, Dannebrogs, og een konge, Frederik den syvende, og bønderne bekræftede med høilydt ja hans ord, hvorpå vi drak kongens skål med stor jubel .... Vi kørte tilbage gjennem Flekkeby og mødte på mange steder danske flag og venlige hilsener; kun eet eneste sted såe vi en med sort-rød-gule farver malet gård, hvor her altså sandsynligviis boede en "Gesinnungstüchtig««. Efter hjemkomsten til Slesvig rejste studentersangerie om aftenen sanıme dag videre til FJensborg for at deltage $i$ festlighederne her og i Gråsten de følgende dage. På disse festligheder skal jeg ikke ved denne lejlighed komme ind.

I det foregående har jeg nu kort opridset det

1) Flensburger Zeitung $2 \%$; 1862 (nr. 1i2). 
ydre forløb af studentersangernes besøg i Sydslesvig, og jeg har gengivet nogle udtalelser, der vidner om stor venlighed fra den sydslesvigske landbefolknings side overfor de danske studenter. I Hiort Lorenzens brev til Skau om festen omtales festdagene betegnende nok som »en god vækker for mangen en hernede, der var ifærd med at glemme, hvorledes glade danske ansigter se ud«. Disse festdage står, skriver han videre, som »de skjønneste dage, vi have oplevet her i Sydslesvig“, og han tilføjer, at hvad der naturligvis mest af alt fryder os og ærgrer tyskerne er den af bønderne hernede viste imødekommen. Det er ikke underligt, at besøgets så vellykkede forløb søgtes udnyttet politisk fra dansk side under den spændte politiske situation, ligesom det omvendt, som af Hiort Lorenzen bemærket, åbenbart gjorde et ret ubehageligt indtryk på de iøvrigt i Mellem-og Sydslesvig så udbredte slesvig-holstenske blade "Altonaer Mercur« og "Itzehoer Nachrichten«. I "Fædrelandet " hedder det bl. a.: Denne fest turde "i al sin uskyldighed have en stor politisk betydning, måskee en større end nogen anden, der hidtil er holdt i Slesvig “.') At landbefolkningen af sig selv var kommen studenterne imøde, skriver det $i$ et senere $n r^{2}{ }^{2}$ ), har ytret ønske om at se dem hos sig, har gjort ofre for at opfylde dette onske og har samlevet med dem, var det end kun nogle timer i hjertelig, aldeles uforstyrret glæde, det er dog sandelig et glædeligt tidernes tegn.

Om stemningen i selve Slesvig by kan der, som ovenfor bemærket, ikke være tvivl. Den var hos den indfødte befolkning overvejende tysk. Det nævnes,

1) Frdrelandet ${ }^{2 \theta / 7} 1862$ (nr. 171).

2) $28 / 71862(\mathrm{nr} .17 \%)$ 
at der under besøget enkelte steder i byen var demonstrativt nedrullede gardiner. ${ }^{1}$ ) Hiort Lorenzen anforer om koncerten i Slesvig, at salen vel var propfuld, men at der desværre næsten ikke sås nogen af borgerne, "der under hele studenternes ophold viste en ikke os, men vore gjæster påfaldende kulde«. Han omtaler endvidere som "en agte tydsk abekattestreg «, at en købmand $i$ hans nærhed alle tre dage havde sine vinduer betrukket med sort flor.

Alligevel var der dog nogle af byens mere fremtrædende borgere, der sluttede sig til det danske parti, navnlig skorstensfejermester senator Petschke, der også var blandt studentersangernes værter, og foruden hain nævner »Itzehoer Nachrichten« som bekendte dansksindede en barber Stühr, en murermester Jessen og en kobmand Nielsen. ${ }^{2}$ ) Som et vidnesbyrd om stemningen skal anføres, at da der i slutningen af ảret 1860 skulde foretages valg til stænderne, anså borgmester $A$. Jørgensen det ikke for aldeles unuligt at "liste" et valg igennem i Slesvig, thi, skriver han ${ }^{3}$, "fjendens leir er temmelig deelt... Jeg har noget håb om, at ca. 50 mand, der $\mathrm{t} ø \mathbf{r}$ stemme på en loyal, kunde decirlere et valg..«. "Hvis vi på en eller anden boug kunne reise en lille fond på ca. $2000 \mathrm{r}$., der mod en yderst lav rente gav lån (på $15-25$ r.) til småhåndvarkere, vilde vi efterhånden befrie mange fra terrorismens kløer. Det er uhyre hvilken trældom folk her holdes $\mathrm{i}$ af de fảe pengemænd. Hele gader ere for det daglige brøds skyld afhængige af Marquarisen, Tuxen, Dr. Paulsen, Salomon etc«. Sådan var altså hans opfattelse.

1) Se beretningen hos Axel Sørensen.

2) Itzehoer Nachrichten ${ }^{12} / 71862$ (nr. 56).

3) A. Jørgensen ${ }^{27} / 111860$ til Regenburg. (Rigsarkivet). 
Men anderledes end $i$ det tysksindede Slesvig var stemningen ude på landet, navnlig i Hütten amt. Sønderjyden M. F. Blaunfeldt, der fra 1850 til 1864 var herredsfoged i Hütten herred, udtaler i sine 1876 udgivne "Minder fra Sønderjylland", at man syd for Slien ikke træffer "dette indpodede eller indgroede had til alt, hvad der er dansk, hos denne tysktalende befolkning, som man finder $\mathbf{i}$ den fortyskede danske befolkning i Angeln nord for Slien. Der mangler naturligvis ikke på tyske og slesvigholstenske elementer $\mathrm{i}$ de kongelige distrikter sønden for Slien, men nian erkjender almindelig, at man er kongelig danske undersåtter og nærer for en stor del selv $i$ de adlige distrikter danske sympathier«. Han erklærer sig fuldkommen overbevist om, "at hvis befolkningen $\mathrm{i}$ disse distrikter $\mathrm{i}$ året 1864 var bleven opfordret til ved almindelig stemmegivning at udtale sig, om den med det øvrige Slesvig vilde forblive dansk, eller med Holsten forbindes med Preussen, den da med langt overveiende flerhed vilde have stemt for tilslutningen til Danmark". Nogen politiske vanskeligheder vilde Blaunfeldt derfor ikke have haft med sit embede, "hvis ikke Holsten og især Rendsborg havde ligget så nær. Men fra dette sæde for fanatiske og fanatiserede oprørere blev der stadig foretaget demonstrationer $i$ herrederne, snart derved, at man søgte at forlede bønderne til opsætsighed og modstand mod ovrigheden, snart derved, at man fra Rendsborg af ligefrem foretog slige demonstrationer ved $i$ storre selskaber at gjennemvandre byerne under afsyngning af oprørske forbudte sange med tilsvarende musik...... - Blaunfeldts skildring hèr af befolkningens stemning svarer jo udmærket til vidnesbyrdene fra studentersangernes besøg. Hans be- 
toning af forskellen mellem Angel og Hütten amt svarer også godt til, at "Itzehoer Nachrichten" ud fra sit standpunkt omtaler Angelboerne som intelligente $i$ modsætning til beboerne af "denne magre landryg ", hvilke sidste anses for at være lette at påvirke af embedsmændene').

Dette sidste var naturligvis omkvædet i de tyske blades omtale af festlighederne, at det hele var lavet af de danske embedsmænd, og at befolkningen selv kun nødigt og kun $i$ ringe tal havde deltaget. $\mathrm{Nu}$ er det selvfølgelig også temmelig givet, at embedsmænd har haft hånd $\mathrm{i}$ hanke ved tilrettelæggelsen af festlighederne. Hvorledes skulde det næsten kunne være andet, vil man med rette kunne spørge. Om udflugten til Dannevirke og de af bønderne hertil stillede vogne bemærker Hiort Lorenzen: "Her ved Slesvig har [herredsfoged] Knudsen naturligvis givet stødet ved at opfordre sine bondefogder ${ }^{2}$ ) til at bringe sligt istand; men der er ikke anvendt noget overtalende middel fra hans side, derom vidner ikke alene den mængde mennesker, der modte os på Thyraborg, men navnlig den omstændighed, at de gamle bønder kjørte deres heste selv, hvilket de visselig skulde have overladt deres karle, dersom de vare blevne tvungne til at give befordringen". Hiort Lorenzen mener dog, at nærheden ved Slesvig har holdt mangen en bonde tilbage fra festen på Thyraborg, der ellers gerne havde indfundet sig. Denne fest overgikkes dog, fremhæver Hiort Lorenzen, langt af festen i Ascheffel »i gemytlighed fra beboernes side«.

1) Itzehoer Nachrichten $20 / 71862$ (nr. 60).

2) Grdet "bondefoged« er det tyske "Bauernvogt«. På dansk bruges "hyfogerl«, (ler hos Feilberg: (j)(lbog over jydske almuenâl angives som: "i landsbyen embedsmand, som stủr under regnskabsmanden..., der atter står under herredsfogden«. 
I spidsen for denne fest stod ifølge »Fædrelandet《 bondefoged Hensen i Aschberg og gărdmændene Goos, Greve (ejeren af bjerget) og $\operatorname{Arp}^{1}$ ). Hiort Lorenzen skriver, at herredsfoged Blaunfeldt, "som dog ellers nok vil vide besked om, hvad hans bønder foretage sig“, aldeles intet vidste, inden deputationen kom hjem fra Slesvig, hvor den havde fremført sit tilbud for komiteens formand, kaptajn Falkenberg. ${ }^{2}$ )

Men hvor stor eller liden virksomhed de danske embedsmænd nu end måtte have udøvet for ordningen af festlighederne ${ }^{3}$ ), så må det ganske afgjort siges, at de anonyme indlæg $i$ de tyske blade ikke havde overvættes held med sig i forsøgene på at reducere befolkningens deltagelse $i$ festlighederne til det mindst mulige. Og når de tyske blade fandt antallet af stillede vogne ringe $\mathrm{i}$ forhold til det antal, befolkningen besad, er det jo en noget urimelig betragtning. Hvorfor $i$ al verden skulde man og netop i høhøstens tid have stillet flere vogne, end der behøvedes til gæsternes befordring?

Fra tysk side følte man da også nødvendigheden af modtræk, og under mottoet: So ein Ding muss ich auch haben foranstaltedes der fra Rendsborg en af

- de af Blaunfeldt omtalte demonstrationer ud på bondelandet: en turnerudflugt fra Rendsborga). Såfremt man tør tro den omtale, som i "Flensburger

1) Fædrelandet ${ }^{26} / 71862$ (nr. 171) og ${ }^{29} / 7$ 1862 (nr. 173).

$\left.{ }^{2}\right)$ Hos Rambusch i hans førnævnte skildring hedder det derimod, at det var på Blaunfeldts tilskyndelse, at bønderne havde indbudt og kørte for gæsterne. Jeg tør dog som før nævnt ikke bygge på hans erindringer.

3) Om branddirektor J. P. Mathiessens forhold til leveringen af vogne fra Breckendorf se Itzehoer Nachrichten ${ }^{30} / \mathrm{s} 1862$ (nr. 70 ) og Flensburger Zeitung ${ }^{10} / 91862$ (nr. 210) og $12 / 91862$ (nr. 212).

4) Flensburger Zeitung ${ }^{23} / 8{ }_{1862}$ (nr. 195), ${ }^{26} / 8$ (nr. 197), 11/9 1862 (nr. 211) og 12/a 1862 (nr. 212). Der omtales på de her anførte steder to turnerudflugter. 
Zeitung " gaves af denne, førte den dog ikke til størie resultater. Havde man fra tysk side insinueret, at danske embedsmænd søgte at gøre festerne tillokkende ved at byde på gratis drikkevarer, så spottedes der nu i »Flensburger Zeitung " over, at de Rendsborgske turnere måtte láde den ene af deres medbragte ølvogne køre tilbage til Rendsborg, uden at de havde fundet aftagere af deres $ø$; kun et par enkelte tjenestefolk, hedder det, havde ikke kunnet modstả den lokkende "bygsaft" (Gerstensaft). At bønderne i byerne mødte modvilje over deres optræden, var kun forståeligt, og det fortælles, at en kobmand i Eckernførde nægtede at sælge en bonde vognsmarelse til hans vogn, hvormed han havde befordret danske studenter!') Naturligvis havde man også fra byerne forud søgt at påvirke befolkningen til, at den ikke skulde deltage i festerne ${ }^{2}$ ).

Aviser og agitatorer gør jo krav på at repræsentere den offentlige mening. Det er vanskeligt at trænge bag disse "repræsentanter" ned til befolkningen selv og finde udtryk for dens egen opfattelse og for, hvad der rorer sig i den. I det foreliggende tilfælde er det imidlertid så heldigt, at der er bevaret et par ytringer, der vistnok kall betegnes som sådanne udtryk. Det er disse, som jeg nu til slut skal behandle.

Forst skal jeg omtale et brev rettet til Laurids Skau og skrevet af byfoged og sandemand Friederich Schroder i Kosel, det sogn, hvor også herredsfoged Blaunfeldt boede. I det på tysk skrevne brev, der er dateret 23. august, men formentlig først afsendt omkring en måneds tid senere ${ }^{3}$ ) nævner Schrø-

1 )Flensburger Zeitung "2/s 1862 (nr. 194).

2) Flensburger Zeitung ${ }^{23} / \mathrm{s} 1862$ (nr. 195).

3) Brevet findes blandt L. Skaus papirer (Kgl. bibl.). Dateringen er som nævnt 23. august (eller 28.??), men poststemplet er fra 21. septbr. 
der først, at han havde haft den fornøjelse ved Ascheffel-festen at køre for nogle af studenterne fra Fahrdorf derhen og tilbage. Under turen op på bjerget vandrede han arm $\mathrm{i}$ arm med to af disse herrer. Den ene af disse, en elskværdig ung mand, underholdt sig navnlig særlig venligt med ham, og da han spurgte ham om hans navn, fik han at vide, at han hed Skau og stammede fra bønder. „På mit spørgsmål, om han var en søn af Laurids Skau, svarede han ja! Nu blev min glæde endnu langt større, da der var bleven mig den lykke til del at træffe sammen med sønnen af forkæmperen for minoriteten $\mathrm{i}$ den slesvigske stænderforsamling og rigsrådsmanden og at blive ført af ham arm i arm under den venligste og behageligste underholdning. $\mathrm{Nu}$ senere var Fr. Schrøder kommen i tanker om, at nan måske ikke have vist sig så taknemmelig overfor Peter S., som han burde, og da han ikke kendte hans adresse, vilde han bede Laurids Skau om at takke sonnen meget fra ham.

Om Ascheffel-festen hedder det videre i brevet, at det var en smuk fest, og at mindet om den endnu længe vil leve hos ham som hos mange andre. Af de mang smukke taler nævner han navnlig den af herredsfoged Blaunfeldt om det loyale sindelag hos beboerne i Hütten herred. Når denne besvaredes af løjtnant Sommer med en tale om, at æren for dette gode sindelag egentlig skyldtes herredsfogdens virksomhed, så vilde Schrøder dog — uden at være egoist - bemrerke, at allerede før den ulykkelige krig og navnlig $\mathrm{i}$ årene $1848 \mathrm{og} 49$ var det lykkedes ham sammen med sin svoger toldassistent C. C. Kinn i Fckernførde, ved fornuftige forestillinger og redegø- 
relser at indvirke sådan på de derværende beboere, at i Kosel og Weseby (Vesby landsby, Kosel sogn) indså næesten alle, med undtagelse af højst 5-6 personer, hvor uretfærdigt der fra det såkaldte slesvigholstenske partis side blev optrådt imod konge og fædreland. Beboerne opforte sig som loyale statsborgere og efterlevede på det beredvilligste alt, hvad de kongelige love krævede. Tvangsforholdsregler var kun, hævdede han, af det onde og avlede en skinloyalitet, der ikke var af varighed. Langt mere kunde der opnås ved rolige og fornuftige belæringer og redegørelser for den retfærdige danske sag.

Om Hütten herred bemærker Schrøder i lighed med Blaunfeldts udtalelser, at det helt igennem bebos af rolige og besindige folk. Med sine kollegaer blandt byfogederne er han dog ikke helt tilfreds, og han betegner flere af dem som ulve i fåreklæder. Han må beklage, at ved den smukke fest i Ascheffel var der af Hütten herreds 22 byfogder kun 4 eller 5 til stede.

Til slut anmoder Schrøder Skau, der står statsroret så nær, om at lade ham tilflyde nogen belæring om, hvilke midler der var de bedst egnede til at føre befolkningen ind på den rigtige vej. Omvendt skulde det være ham en glæde fra tid til anden at give Skau meddelelse om forhold og stemninger i det sydligste Slesvig, meddelelser, som han troede næppe vilde være Skau, en regeringen så nærstående mand, uvelkomne. En ting vilde han gerne straks bemærke, nemlig, at det burde forbydes post- og toldembedsmænd i Sydslesvig, hvor kirke- og skolesproget var tysk at tale dansk ved deres embedsforretninger og i de kongelige lokaler. Sådant tog publikum nemlig anstød af og betegnede det som demonstrationer. 
Laurids Skau greb med glæde den fremstrakte hånd, og $\mathrm{i}$ et brev skrevet kort efter modtagelsen af Schrøders fremhævede han i lighed med den politik, som det danske stændermindretal i 1860 havde dyrket,") i kraftige vendinger modsætningen mellem bøndernes og ridderskabets interesser. ${ }^{2}$ ) "Jeg har tidt forundret mig over, skrev han, at bondestandens deputerede fra det sydlige Slesvig ikke kunne indsee, at deres interesser som of test ere modsat godseiernes og ridderskabets, og at de ville opnåe langt mere ved at alliere dem med nordslesvigerne. At vi tale forskjelligt sprog, gjur ikke det allermindste; thi når vi skulle gribe $i$ pengepungen, er offeret det samme, hvad enten vi tale dansk eller tydsk. Vi blive stedse langt tilbage med alle reformer, når Angliternes evige skrål i sprogsagen skal afgjøre, hvorledes der skal stemmes også i materielle anliggender, og - det er mærkværdigt, at borger- og bondestandens deputerede ikke kunne indsee, at ridderne og godseierne bidrage til at vedligeholde sprogstriden, a l e ne for selvat fiske i rort vand“. For at bruge et af Skau selv tidligere anvendt udtryk, svingede han kraftigt med frihedsfanen. Han drog stærkt til felts mod den privilegerede reprasentation i stænderne for

1) Se herom min afhandling "Den slesvigske standerforsamling i 1860«, Hist. tidsskr. 9 H. III 279 ff.

$\left.{ }^{2}\right)$ Ved Schreders brev til Skau findes en dansk og en tysk koncept til skaus svar, den danske er dateret 24. septbr. I den danske koncept findes et liengere stykke, der er overstreget og ikke findes $i$ den tyske. I det overstregede hedder det bl. a., at Skau vil sende en afskrift af Schrøders brev til sønnen Peter, der er ansat i slesvigsk ministerium. Dette forklarer formentlig, at der i Regenburgs papirer blandt brevene fra $L$. Skau findes en afskrift af Schrøders brev. Peter $S$. har vel ladet afskriften gá videre til Regenburg, der samlede på alt, som kunde oplyse om slesvigske. forhold. 
ridderskab og godsejere, der næsten gjorde gennemførelsen af en ny matrikel umulig. Han omtalte sin statte af det af den stænderdeputerede for 15 . landvalgdistrikt (Eckernførde), gdr. J. D. Arp, fremsatte forslag om hoveriets afløsning, og han fremhævede sit eget forslag om at sætte alle embedsmænd på fast gage. Når blot bønderne og borgerne i stænderforsamlingen "ville slutte sig sammen om mig, skriver Skau selvfolende, skulle vi snart slippe fri for en deel af de byrder, der nu hvile på os.... Bønderne i Sydslesvig og i Nordslesvig må forene dem om at bekæmpe fælles fjender; vi ville da være sikkre på seier«. Han opfordrede kraftigt Schrøder til at gare bønderne dette indlysende på hans egn, og han omtalte igvrigt, at det var hans plan engang at berejse Sydslesvig for at stifte bekendtskab med befolkningen. Der blev dog vist intet af denne plan, og heller ikke bragte den indledede forbindelse med Schrøder videre udbytte, så vidt ses. Tanken om det politiske interessefællesskab mellem syd og nord må ellers betegnes som frugtbar. Aret efter synes det at have været pả tale at soge forbindelse med den ovennæunte Arp, og der tales også om mulighed for tilnærmelser mellem Krüger og gårdmand Andreas Hansen, Grumby, en af tyskernes ledende mænd ${ }^{1}$ ).

Byfoged Fr. Schrøders brev måtte hos Skau styrke hans opfattelse af det betydningsfulde i studenterbesøget. Men allerede tidligere havde han i et brev til H. R. Hiort Lorenzen af 11. August, skrevet fra Ems, hvor han for sit helbreds skyld opholdt sig,

1) Se herom brev fra Fr. A. Ladiges, Borghorster-Hütten, til L. Skau ${ }^{21} / 5$ 1863 og brev fra C. II. Moller, Skovgård, til L.. Skau ${ }^{24 / 6} 1863$ (Kgl. bibl.). 
udtalt sig herom'). "Navnlig har det, bemærkede han, i høieste måde forbauset mig, at studenter og bønder kunne fraternisere med hinanden, og at de sidste endog leverede vogne, så at der kunde holdes folkefest på Hüttener bjerge.... Han anser følgerne for uberegnelige, thi hvem kan forudse, om ikke bønderpigerne kunde fả lyst til på ny at få sig en svingom med de lystige studenter? "Det er den rigtige taktik at føre krigen midt ind $i$ fjendens land; kun stedse mere sydpå - indtil Eidercn; sảledes bør det være«.

Den venlige modtagelse, som studenterne havde mødt hos landbefolkningen i Sydslesvig, bevirkede ret naturligt, at sangerne, da de var vendte tilbage til Kobenhavn, fik travlt med takkeskrivelser. Den 5. august afsendtes 9 af bestyrelsen underskrevne tyske taksigelsesskrifter til bønderne i Ascheffel, Kosel, Breckendorff, Owschlag, Bustorf, Klein Dannewerk, Ober Selk, Husby og Churburg. I anledning af disse indlob der til sangforeningen to tyske svarskrivelser fra bonderne i Breckendorf og Owschlag. .De er daterede fra august, men sendtes først ved et brev af 25 . oktbr. fra rektor S. Povelsen i Slesvig til overlærer Ottesen ${ }^{2}$ ).

Povelsen undskylder i sit brev først den sene oversendelse, men bemærker derpå, at det også for en del er med overlæg, "både at De så sent få disse, og at De ikke få flere lignende skrivelser, hvilke det ikke vilde have varet vanskeligt at erholde, dersom vi blot med et ord vilde have mindet vedkommende derom. Men sålænge den ự̆øvende politimagt er så

1) Brevet findes pả det kgl. bibl.

2) De navnte skrivelser findes i studentersingforeningens arkiv. 
ligegyldig eller svag, at den ikke vil eller kan sikre de mænd, der lægge et loyalt sind for dagen, mod personlig overlast i nabobyerne [Rendsborg, Eckernførde!], anse vi det for uklogt fra vor side at gjøre eller bidrage til noget, der kunde bringe de svage $i$ ånden til at fortryde den loyale optræden, som ellers falder dem så naturlig“. Han anså det derfor ikke for klogt, om man offentliggjorde de nævnte skrivelser, men på den anden side mente han sig ikke berettiget til at forholde studentersangforeningen "disse svar, dcr, som vi håbe, vilie bidrage til, at de kjøbenhavnske studenter i fremtiden, i større eller mindre skarer, ret ofte ville gæste Sydslesvig“.

Af de to skrivelser bærer den fra Breckendorf 10 underskrifter, den fra Owschlag 5. Skønt udtrykkene i dem ikke er helt ens, er indholdet dog ganske det samme, og dette som Povelsens lige næunte ytringer kunde vel tyde på, at den, der har konciperet dem, ikke stammer fra bøndernes egen kreds. Skrivelserne begynder med en tak for studentersangforeningens modtagne takkeskrivelse af 5. august og med at udtrykke, at samværet også hảr været bønderne uforglemmeligt. Det har båret den smukke frugt, at man har erfaret, at trods forskelligt sprog kan man leve endragtigt sammen. Studenterne opfordres derefter til hyppigt at besøge dem og forsikres om, at de stedse skal være velkomne. Endelig slutter brevene med det fælles udbrud: "Kongen og vort elskede fælles fædreland leve«!

Lad da disse ord være slutningen på denne omtale af studentersangernes færd til Sydslesvig i juli 1862 og udtrykket for, hvad der forenede de danske studenter og de plattysktalende bønder, før uvejret 1864 sprængte de århundredgamle bånd. 


\section{3. \\ Fra Tonder provstl efter krigens ndbrud 186"*). Indledning.}

Ved Frederik den syvendes død den 15. november 1863 brød stormen ind over det danske monarki, men den bestod, om man så må sige, af to noget uensartede elementer: det slesvig-holstenske og det preussiske. Begge sigtede ganske vist mod det danske monarkis tilintetgørelse, men de var ellers nærmest modsatte. Det forste viste sig straks fra første færd åbent, det vilde en ny tysk småstat, et "Slesvig-Holsten" under de augustenborgske hertuger. I dagene lige efter Frederik den syvendes død proklamerede arveprins Frederik af Augustenborg sig som den retmæssige arvtager til de to hertugdømmer og kaldte sig "hertug Frederik den ottende“. Det preussiske element, der vilue en magtog territorialforggelse for den preussiske stat, holdt sig derimod i begyndelsen skjult. Bismarck nojedes med at hævde, at Danmark ved novemberforfatningen havde brudt aftalerne fra $1851-52$ med de tyske stormagter, og at aktionen mod Danmark tilsigtede at få disse aftaler opfyldte. At Christian IX var monarkiets retmæssige arvtager, sattes altså $i \quad o g$ for sig ikke i tvivl. Bismarck fik til sin politik foreløbig tilslutning hos Østrig, og da den tyske

*) Den følgende skildring bygger i hovedsagen på de fordrevne embedsmænds indberetninger til slesvigsk ministerium og af disse navnlig på provst J. M. L. Hjorts. De findes i slesvigsk ministeriums arkiv i rigsarkivet. Nrermere henvisninger fra teksten til de forskellige beretninger har jeg ment at kunne undlade. Endvidere bygger skildringen på J. M. L. Hjorts i rigsarkivet beroende privatarkiv, der indeholder en række breve, de allerfleste fra 1864. Breve, der citeres uden nærmere angivelse, findes i adressatens privatarkiv i rigsarkivet. - Meddelelser om begivenhederne i Slesvig siden den preussisk-østerrigske invasion. (Den 1ste november $1 \times 64$ ). 1864 citeres som meddelelser om invasionen. 
forbundsdag ikke længer vilde slå fŏlge, gik de to storrnagter frem på egen hånd. I slutningen af december 1863 var Holsten og Lauenborg bleven besat af tyske forbundstropper, og da Danmark i januar 1864 afslog Østrigs og Preussens krav om novemberforfatningens umiddelbare tilbagetagelse, overskred de to nævnte magters hære den 1. februar Ejderen for at tage Slesvig i pant.

Efter Danmarks afslag på Østrigs og Preussens krav måtte de danske embedsmænd i Slesvig tage under alvorlig overvejelse, hvorledes deres stilling vilde blive under en mulig fjendtlig besættelse af hertugdømmet. De danske embedsmænd måtte frygte både de fjendtlige hære og den slesvig-holstenske bevægelse, der fra Holsten kunde ventes at ville forplante sig nordpå. $\mathrm{Og}$ endelig kunde man $\mathrm{i}$ Mellemslesvig vente kraftige udbrud af den stadig herskende misfornøjelse hos befolkningen med den i 1851 indførte danske sprogordning. Sådanne udbrud måtte forventes navnlig at ville rette sig mod sprogordningens bærere, de danske præster. Den mand, der her ubetinget må siges at have haft hovedparten af byrden, var $S$. Aleth Hansen, provst for Flensborg og Gottorp provstier. Fra denne er der også bevaret en længere skrivelse til departementschef A. Regenburg omhandlende, hvad præsterne eventuelt kunde komme ud for under en okkupation, og hvordan de så skulde stille sig.

I denne skrivelse, der er dateret den 21. og 22. januar, fortæller Aleth Hansen forst, at de havde været forsamlede en del præster for at udtale sig for hinanden om disse spørgsmål. Alle havde de været enige om, at det var det retteste og tillige det, der var regeringen mest kærkomment, at de forblev 
på deres pladser, så længe det blot nogenledes var muligt. Derfor vilde de også eventuelt, om end under protest, efterkomme en fordring om at afskaffe dansk i kirke og skole. Ligeledes vilde de under protest udrede de skatter og øvrige ydelser, der måtte blive dem afkrævede. Endvidere var de tilbøjelige til at ville bekendtgøre anordninger fra en eventuel provisorisk regering, når disse anordninger ikke ligefrem gik mod kongens rettigheder. Derimod mente de at måtte vægre sig, om kirkebønnen afskaffedes, og en ny påbødes. Med hensyn til en eventuel afsættelse mente de fleste at måtte gå, når de herom modtog en skrivelse, medens dog også nogle udtalte sig for, at man ikke skulde vige uden for anvendelse af ligefrem vold. Navnlig med hensyn til spørgsmålet om kirkebønnen ønskede Aleth Hansen meget en udtalelse af Regenburg. Han endte med, at denne iøvrigt ikke måtte tro, at de var forknytte: "det er vi ingenlunde; men på den anden side indsee vi, at vi måe være fattede på alt“.

Regenburgs svar på Aleth Hansens forespørgsler er af 28. januar, og dette svar vidner smukt både om Regenburgs klogskab og hans mandige karakter og tillige om, at han, den overordnede, ikke vil spænde fordringerne for stærkt til dem, der er hans undergivne og står på de udsatte poster. $\left.{ }^{1}\right)$ Han begynder brevet med følgende kraftige udtalelse: "Skulde, hvad Gud forbyde, vore egne blive occuperede af fjendtlige tropper, så må hver mand blive på sin post, sålænge det er physisk og moralsk muligt“. Ved almindelige regler, fortsatte han, lod det sig imidlertid ikke bestemme, hvor den moralske mulighed ophørte, navnlig da det var uklart, hvilken karakter okkupationen 1) Svaret findes i kopi vedlagt Aleth Hansens foresporgsel. 
vilde antage, og hvordan befolkningens stilling blev til denne. Meget træffende bemærkede han, at fjenden vistnok vilde undgå alt, som kunde tyde på den hensigt at forandre de statsretlige forhold. "Selv om han har den nok så meget, byder politiken ham at skjule den. Jeg troer derfor ikke, at han vil befale noget, der kan komme i strid med embedsmændenes samvittighed, træde kongens ret for nær osv«. Naturligvis måtte ingen embedsmand foretage sig noget, hvorved en andens suverænitet end kongens anerkendtes, men ellers skulde man adlyde blindt. "Befales, at kirken aldeles skal lukkes, så adlyder man og søger på anden măde at sørge for befolkningens religiøse vel. Befales, at dansk prædiken skal bortfalde, så adlyder man; ja selv en befaling, at kirkebønnen for kongen skulde bortfalde, måtte adlydes, medens bøn for en prætendent eller fremmed souverain måtte undlades. Jeg vilde, hvis noget sådant mod forventning skulde blive foreskrevet, aldeles lade kirkebønnen bortfalde og så afvente følgerne«. Anderledes end ved en fjendtlig okkupation, hedder det videre i Regenburgs brev, vilde forholdene stille sig, om man fik en af fjenden understottet revolution. Befolkningen frygtede ikke den danske regering, hvis mildhed, for ikke at sige svaghed den kendte, men den var bange for tyskerne og den værste slags af disse, de slesvig-holstenske partimænd. Disse havde desuden i Holsten erhvervet sig en vis virtuositet $i$ at skabe bevægelser, og fik en flok af dem lov at udfolde deres virksomhed, vilde de have let ved sat sætte de onde kræfter i bevægelse, terrorisere de gode og rive magten til sig«. Indtrådte dette, vilde de loyale embedsmænds stilling snart blive uholdbar. Men om muligt skulde man sørge for at 
blive sendt bort og ikke gøre fjenden den fornøjelse selv at rejse bort. Regenburg troede, at han selv vilde handle sådan, men udtalte, at han følte så godt, at. det var let at sidde i København og give regler, "medens der kræves mere end almindeligt mod til at handle derefter og underkaste sig de mulige følger. Jeg for min del skal i al fald ikke bebreide nogen, om han ikke lod det komme til det yderste, og skulde gjøre alt mit til at forsvare vedkommende for ubeføiede angreb». Iøvrigt kunde han, skrev han til slut, ikke opgive det håb, at et fjendtligt angreb måtte med Guds hjælp kunne tilbageslås. Han henviste til den berømmelige kamp den 2 . april 1801, hvor danskerne på dårlige blokskibe stred mod Englands. tapreste sømænd. Skulde det da være umuligt at sende Wrangel og hans bande tilbage fra Danmark med blodige pander? "Dog sagen ligger $\mathbf{i}$ Guds hånd. Gid vi kun alle må have den bevidsthed at have gjort. vor pligt og intet at have forsømt«.

Regenburgs håb skulde ikke gå i opfyldelse. Natten mellem den 5. og 6. februar gik de Meza og hans hær fra Dannevirke nordpå, kort efter fulgt af "Wrangels bande«. Trange tider oprandt for den dansksindede del af Slesvigs folk og for de danske embedsmænd. For disse blev det af skæbnesvanger betydning, at der ikke blot kom en fjendtlig okkupation, men at denne som af Regenburg formodet ledsagedes af et revolutionært slesvig-holstensk røre. Dette udfoldede sig i ly af okkupationen og for en stor del tålt eller endog fremmet af denne.

\section{Slesvig-holstenernes fordrivelse af danske}

\section{embedsmand.}

Der skal nu i det følgende fortælles lidt om, hvordan - for at bruge Regenburgs ord - den værste 
slags af tyskere, de slesvig-holstenske partimænd, gjorde stillingen uholdbar for de fleste danske embedsmænd $i$ en bestemt del af Slesvig, nemlig $T ø n-$ der provsti. Det er dog.ikke hensigten her at give nogen helt udtømmende skildring af forholdenes udvikling, og i forste række vil det være de gejstlige embedsmænds stilling, som vil blive behandlet.

Først et par ord om Tønder provsti og dets embedsmænd. Ved Tønder provsti var der den særlige interesse, at det indeholdt rent danske sogne, rent tyske og endelig blandede, altså sådanne, der stammede fra den danske sprogordning 1851. De blandede sogne var foruden selve Trnder by sognene SønderLøgum, Brarup, Humarup, Ladelund, Karlum, Klægsbøl, Medelby, Ubjærg, Avntoft og Læk. Af danske sogne fandtes der i provstiet 13 , medens resten var rent tyske. I spidsen for provstiet stod kirkevisitatoriet, bestående af provst og amtmand. Provsten, der tillige var hovedpræst i Tønder by, var fra 1860 I. $M$. L. $H_{j}$ ort, en brodersøn af den kendte professor $P$. Hjort. I samme år var også grev L u d v. F r. H. B r ockenhu us-Schack bleven udnævnt til amtmand. Begge var de ivrige for den danske sag. Dette gjaldt derimod langtfra diakonen i Tonder, C. E. Carstens, der også havde siddet fra tiden før 1848. Han var forøvigt født i Tønder. En ganske særlig interesse havde det naturligvis, hvilke præster der sad i de blandede sogne. Af disse stammede tre præsterne i Humdrup, Ubjærg og Medelby - fra tiden før 1848. Om pastor Christiansen i Medelby henviser jeg til min udførlige skildring tidligere her $\mathbf{i}$ "sønderjydske årbøger". De to andre præster má vist henregnes til de tysksindede. Alle de andre præster $i$ de blandede sogne var ansatte efter treårs. 
krigen og dansksindede. Af præsterne $\mathbf{i}$ de rent danske sogne skal lige nævnes Johannes Kok i Burkal, forfatter til bogen »Det danske folkesprog i Sønderjylland..... $\left.\alpha^{1}\right)$ Præsterne i de tyske sogne var ganske overvejende tysksindede, således anføres det om præsterne i Bøking herred, at med undtagelse af $P$. Petersen i Dedsbøl og J. Andresen i Lindholm var de sikkert alle slesvig-holstensksindede. ${ }^{2}$ )

I en indberetning til ministeriet af 2. februar 1864 havde grev Brockenthuus-Schack om forholdene $i$ amtet udtalt, at klagerne $i$ dette altid havde indskrænket sig til den bestående sprogordning, og til at der blev ansat et uforholdsmæssigt antal kongerigske embedsmænd i Slesvig. Nogen egentlig sympati for prætendentens person troede han ikke der var, men alligevel var han overtydet om, at prætendenten $i$ tilfælde af en invasion vilde blive proklameret i Tønder by, marskherrederne og i Kær herred. Herved vilde man opnå, at klagerne over sprogordningen for bestandig blev afhjulpne, og at den yndede administrative forbindelse med Holsten blev genindfort.") Grevens indberetning viser, hvad man også kunde vente, at den kommende storm navnlig vilde kaste sig mod de danske præster i de blandede sogne.

En underlig trykket stemning har der sikkert hersket i dagene forud for Dannevirkes rømning både hos de danske embedsmænd og hos befolknin-

1) Se om ham min afhandling "Sønderjydsk sprog-og folkemindeforskning mellem krigene«. (Danske studier 1919) $137 \mathrm{ff}$.

2) Herredsfoged H. T. V. Christensens indberetning 29. janr. 1864 til ministeriet. A. Linvald: Stemninger og tilstande i Sønderjylland ved krigens udbrud 1864. (1920) 21.

3) Linvald anf. arb. 9. 
gen. Med hvilken spænding har man ikke grebet Københavnsaviserne eller lyttet til rygterne sydfra. Allerede i nogen tid var der bleven agiteret med slesvig-holstenske flyveblade og flyveskrifter og ved udsendinge sydfra, og stemningen var ophidset. Nu kom den 6. februar efterretningerne om den danske hærs tilbagetog, og hermed gaves signalet til pøbeludskejelser og voldshandlinger mod embedsmændene. Sondagen den 7 . februar ved middagstid drog en afdeling danske artillerister med kanoner på tilbagetoget fra Frederikstad nordpå gennem Tønder. Til dem sluttede sig flere danske embedsmænd samt gendarmeriet og politibetjentene, og byen blottedes herved for al udøvende politimagt. Først den 13. februar besattes byen af preussisk militær, og i mellemtiden havde altså "det suveræne folk« frit spil. Men allerede før de danske troppers afmarch gennem Tønder var iøvrigt pøbeludskejelserne begyndte, både i selve byen og rundt om i provstiets øvrige sogne.

Ifølge den udførlige beretning, som provst Hjort senere overfor ministeriet gav af begivenhedernes gang, viste der sig den (i. februar stor bevægelse på Tønder bys gader. Folk samledes i flokke, støjede og sang oprørsvisen "Schleswig-Holstein meerumschlungen«. Dog hørtes endnu også "Den tapre landsoldat«. En mængde flygtninge kom til byen sydfra. Efter de danske troppers bortdragen den 7. dannede borgerne en sikkerhedskomité for at opretholde ordenen. Hjort mærkede dog ikke stort til bevægelsen, da han boede afsides bag kirken. Efter sin søndagsprædiken om eftermiddagen gik han ud til amtmanden, men mødte på vejen borgmesteren og politimesteren, kancelliråd J. H. Holm. Denne fortalte om den oprettede sikkerhedskomité, og at denne vilde værne fami- 
lierne, når mændene fjernede sig. Der forlangtes, at embedsmændene ikke måtte være i byen efter klokken 5-6; ellers risikerede de at blive molesterede. Holm rådede ham til at tage bort. Da Hjort kom ud til amtmanden, traf han denne rejseberedt og fik at vide, at flere embedsmænd allerede havde forladt byen. Amtmanden synes i høj grad at være bleven overvæluet af udsigten til forestående uroligheder. Han flygtede til Ribe, men under flugten og efter ankomsten hertil fik han dog samvittighedsskrupler over den hovedkulds bortrejse. Den 9. skrev han et Iængere brev til Hjort, hvori han først og fremmest bad denne tilgive ham, at han havde været så yderst ukærlig imod ham og hans kone ved Hjorts sidste besøg. Han havde imidlertid i det ojeblik været så oprørt over Tønderanernes utaknemmelighed og hele færd og tillige i en så bevæget og nervøs stemning, at han ikke havde været sig selv. Det havde fortrudt ham, at han ikke havde tilbudt Hjort og hans familie at køre med ham. Den 8 . havde han været betænkt på, om han ikke skulde kunne vende tilbage og indtage sin stilling. Men han havde da erholdt en depeche fra byen om, at dette måtte anses for en umulighed. Han endte med at takke Hjort for samarbejdet $\mathrm{i}$ de forløbne år og med ønsket om, at fremliden igen måtte bringe dem sammen: "I Tønder bliver det vel næppe«.

Vi vender igen tilbage til provst Hjort og hans besøg hos amtmanden den 7 . Nogen opmuntring til at holde ud på sin post kan han ikke have fået af dette. Da han gik fra ham, mødte han atter Holm og opfordredes af denne på ny til at drage bort. Endnu var han dog tvivlrådig og gik derfor hen til fysikus F. F. Ulrich, der skulde vise sig som den mo- 
digste af de tønderske embedsmænd. Men Hjort traf desværre, som han siger, ikke Ulrich hjemme og bestemte sig nu for at følge borgernes befaling. Han drog med sin familie til Skadst præstegård, der lå i hans provsti, og vilde her lade familien blive og selv snarest "gren vende tilbage til embedet. Undervejs mødte de i Højer en stor syngende pøbelhob, men kom dog uhindret til Skadst. I sin nævnte beretning skriver Hjort, at det mest trykkende og skændige ved sagen var, "at det hele var anlagt således, at det skulde see ud, som embedsmændene var flygtede af sig selv, medens borgerne fungerede som beskyttere. Men i virkeligheden var det borgerne, som udjog os, og de havde forfattet proskriptionslister, som ikke bleve fravegne«. Det var, erkender han, urigtigt, at han drog bort, men han mente, at det tjente ham til undskyldning, at han så hurtigt venite tilbage.

Han havde bestemt sig til at gøre dette allerede tirsdag morgen den 9. Fastelavnsmandag -- den 8. - vilde han blive i Skadst af hensyn til de optøjer, der denne dag kunde ventes. Men mandag eftermildag modtog han fra fysikus Ulrich et brev med indtrængende anmodning til ham om endelig snarest mulig atter at komme tilbage. Ulrich beklagede, at han ikke havde fået talt med ham inden afrejsen, da det sả măske var lykkedes at holde på ham. Det var hans overbevisning, at han godt kunde være bleven. Han bad ham nu om at rejse så tidlig fra Skadst, at han kunde være $\mathrm{i}$ Tønder før tirsdag middag. Opad dagen henad aften var jo nemlig, bemærkede han, adskillige af pøbelen i en utilregnelig tilstand, og Hjort kunde derfor udsætte sig for at blive forhånet ved at køre gennem byen. For resten havde 
borgerne hidtil holdt mønsterværdig orden. Nogle fulde bander havde nok sunget og talt, man havde stukket sine slesvig-holstenske og tyske klude ud og nedrevet kongelige navnechifre på posthuset og toldboden, men det var også det hele. Ulrich selv var uhindret gået gennem byen til en patient, men han gik iøvrigt ikke ud, uden der kom bud efter ham, for ikke at irritere folk. NårFastelavnsmandag var ovre, troede han, at det værste vilde viere forbi. Til slut fortalte han, at en tøndersk småmand ikke havde kunnet få ro, fordi Hjort havde ladet sig skræmme bort, og om natten var vedkommende gået til Møgeltonder $i$ den formening, at Hjort var der, eller at man der vidste, hvor han var.

Efter modtagelsen af Ulrichs brev afrejste Hjort øjeblikkelig til Tønder og kom dertil kl. 11-12 om aftenen. Byen var da $\mathrm{i}$ største røre og pøbelen $\mathrm{i}$ færd med sine udskejelser. Da Hjort ikke kunde komme ind $i$ sin bolig hvortil noglen lå hos en anden mand, tog han ind i "Humlekærren" og blev der om natten og var her orevidne til pøbelens forfærdelige tumult og excesser. Trods sikkerhedskomiteen gik det også ud over fysikus Ulrich og hans hus, hvor ruderne blev slåede ind, og hvorfra man kun med nød og næppe holḍt pobelen ude. Ulrich måtte nu selv en kort tid forlade byen og tage til Møgeltønder.

Tirsdag den 9. skulde prætendenten proklameres, og da Hjort ikke vilde overvære dette, tog han om morgenen atter bort fra Tønder. Også politimester Holm, der var forblevet $\mathrm{i}$ byen, måtte denne dag tage bort, efter at han havde forsøgt, men forgaves, at organisere de dansksindede til modstand mod den påtænkte demonstration. Byen var helt fuld af slesvigholstenske flag. Efter hvad der senere berettedes 
Hjort af øjenvidner, skete proklamationen på en temmelig uheldig måde. Flere af de mere ansete borgere holdt sig tilbage derfra. Talen holdtes af en destillateur Dreger, og under den faldt flaget ned fra kirketårnet. Til højtideligheden hørte, at man skulde slutte med salmen "Nun danket Alle Gott", der skulde synges med blottede hoveder. Men allerede ved 2.-3. vers kom hattene på, og man kunde ikke salmens ord. Det gudsbespottelige i den hele akt, skriver Hjort, gjorde et så stærkt indtryk på en kabmands hojtfrugtsommelige kone, at hun faldt $i$ en krampagtig gråd, senere nedkom med et dødfødt barn og nogen tid efter døde under svære lidelser.

Fra om onsdagen tog Hjort ophold i Møgeltønder for at være ved hånden til snarest mulig på ny at tiltræde sit embede. Møgeltønder, denne kongerigske enklave med den udpraget dansksindede befolkning, blev i det hele et slags hovedkvarter for de flygtede og forjagede danske embedsmænd. For disse har det vel spillet en væsentlig rolle, at det ikke var slesvigsk, men kongerigsk grund. Hertil vendte også nu grev Brockenhuus-Schack tilbage fra Ribe med samt herredsfoged C. A. Kiær. Om torsdagen tog Hjort ind til Tønder for at ekspedere de indkomne provstisager, og han tilsagde konfirmanderne til at møde næste lørdag. For at hente nogle sager, som han om søndagen havde afleveret til pastor Carstens, gik han op til denne, men modtoges på den alleruhøfligste måde. Carstens kastede sig selv på sofaen og lod provsten stå og udbrød: "Hvor vover De at komme her? Det souveræne folk har erklæret at ville af med alle danske embedsmænd, og folket vil vide at sætte sin villie igjennem«. Hjort svarede, at han ikke veg for en unavngiven pøbelhob. Kom en navngiven mand og 
på sit ansvar tog embedet med magt, vilde han vige, men før ikke. Han mindede også om den aflagte embedsed, som Carstens selv havde aflagt.

Efter Hjorts tilbagekomst til Møgeltønder indtraf her efterretningen om den preussiske civilkommissær friherre v. Zedlitz' bekendtgørelse af 8. februar om overtagelsen af Slesvigs bestyrelse.) Ved denne suspenderedes den danske konges regeringsmyndighed som følge af "de allierede armeers våbenfremgang«, og v. Zedlitz overtog - foreløbig alene - udøvelsen af den højeste regeringsmagt i landet, indtil den osterrigske civilkommissær ind traf, herefter vilde de i fællesskab udøve magten. Den preussiske øverstkommanderende Wrangel havde ved bekendtgørelse af 7. februar forelobig stadfæstet samtlige civile embedsmænd i Slesvig i deres embeder, for sả vidt de underkastede sig civilkommissærerne. Lnder henvisning hertil opfordrede $v$. Zedlitz nu i sin bekendtgørelse embedsmandene til at afgive en skriftlig erklæring om, at de under besættelsen underkastede sig dels den øverstkommanderende og dels civilkommissærerne. Denne erklæring skulde indsendes inden 8 dage. De embedsmand, der indgik denne forpligtelse, vilde kunne regne med beskyttelse og understøttelse i deres embedsforelse, "sålænge de forblive samme troe og ellers ikke ved deres forhold i eller udenfor tjenesten give anledning til at fjernes fra deres embeder". Der var truffet foranstaltninger til at hindre gentagelse af excesser, og navnlig vilde der ikke blive tålt politiske demonstrationer, hvorved afgørelsen af successionsspørgsmålet foregrebes. Bekendtgørelsen var

1) Aftrykt i Meddelelser om invasionen. $104 \mathrm{ff}$. 
således fuld af kønne ord, men de viste sig snart for den væsentlige del at være tomt spilfægteri.

Lørdag morgen tidlig holdt de fordrevne tønderske embedsmænd i Møgeltønder krigsråd, og de blev her enige om at underkaste sig de betingelser, der opstilledes i v. Zedlitz' proklamation. Lordag formiddag tog de ind til Tønder, hvortil der samtidig var ankommet preussisk militær. Dette var opstillet på torvet, og en stor mængde mennesker var forsamlet, da Hjort kom kørende ind. Da folk fik øje på ham, blev der en frygtelig hujen og støjen med råbet "Hannemand heraus«, man kastede med snebolde og stimlede sammen om vognen. Den preussiske øverstkommanderende skred imidlertid ind og talte folk strengt til, og Hjort kom ind i sit hus. Han læste som bestemt den dag med konfirmanderne, der så godt som alle var mødt, men holdt ingen prædiken om søndagen, hvorom han heller ikke havde bekendtgjort noget. Den 15. sendte han og greven deres underkastelseserklæringer med stafet til Flensborg, og greven rejste selv ned for at tale med Zedlitz. På hans anmodning til denne om at få understøttelse til atter at indfore de forjagne embedsmænd $i$ deres embeder, svarede Zedlitz dog, at det var ikke værd, da de måske igen om kort tid vilde blive fjernede.

Fra om lørdagen opholdt Hjort sig nu uafbrudt $i$ Tønder bortset fra et kort besøg i Møgeltønder og et senere i Skadst for sidste sted at se til sin familie. Denne lod han en halv snes dage senere vende hjem til Tønder. Mandag den 15 . havde et par mænd villet hejse oprørsfanen på en flagstang, som Hjort privat havde anbragt $i$ sin have. Han gik imidlertid ned til dem og skar tovet over, så flaget ikke kunde hejses. Derefter lod han flagstangen save over. Et par dage 
senere, efter at han havde bebudet den følgende søndag at ville holde dansk priediken, blev der en aften kastet sten paa hans vinduesskodder, og da han kom ned, havde man hejst oprørsfanen på en stang, der var sat til stumpen af hans flagstang. Hjort ilede straks over til den militære befalingsmand - preusserue var i mellemtiden afløst af østrigere --, og denne skred alvorligt ind mod de af hans folk, der forledt af borgere havde været med til optøjerne. Fanen fra Hjorts have blev senere bunden til posten på torvet. Kommandantens tilbud til Hjort om en sikkerhedsvagt afslog denne, da han, så længe han fungerede som præst, kun vilde stå under Guds beskyttelse.

Naturligvis blev der stor opstandelse i Tønder over den af Hjort bebudede danske prædiken den 21. februar. Der gik bud fra dor til dør hos det tyske parti for at få det hindret, og man påtænkte i stedet for at synge salmerne at synge Schleswig-Holsteinvisen og så ved råb ellèr magt få Hjort ned af prædikestolen. Hele lørdagen og søndag formiddag kom den ene melding efter den anden til Hjort fra venner og halve venner gående ud på, at han endelig ikke måtte prædike. Det gjorde han alligevel. Der var mange mennesker i kirke, navnlig kvinder, men også mand, og mange tyske, som ellers ikke gik i kirke. Da det kom til stykket, turde man alligevel ikke lave optøjer, og Hjort mener, at grunden hertil sikkert $i$ høj grad var, at nogle østrigske soldater var i kirke for deres andagts skyld. Kommandanten skal desuden have haft en patrouille i beredskab i tilfælde af optøjer. Hjort holdt en bodsprædiken og talte om alt det onde, der var kommet til udbrud i de nærværende tider, og al den nød, der var bragt over uskyldige familier. 
Med denne første danske prædiken var, som Hjort skriver $\mathrm{i}$ sin senere beretning, isen brudt, og han kunde nu uhindret vedblive at fungere. Et par dage efter fik han besøg af pastor Carstens, og der var nu ikke mere fra dennes side tale om uhøfligheder mod hans overordnede provsten eller påberåbelse af "det souveræne folk«. Den følgende søndag havde Hjort dansk konfirmation og en helt fuld kirke, og også de par gange senere hen, på hvilke han endnu inden sin afsked holdt dansk gudstjeneste, havde han en velbesøgt kirke. Den tyske gudistjeneste hos pastor Carstens var derimod dårligt besøgt. Carstens var ikke nogen stor prædikant, og da han senere efter Hjorts afskedigelse fik overdraget at forrette også den danske gudstjeneste, svandt kirkegængernes antal ved denne ind til nogle få. $\left.{ }^{1}\right)$ Efter $\sin$ første danske gudstjeneste lod Hjort ligeledes skolerne begynde på ny, men de blev dog hovedsagelig kun søgte af dansksindede folks børn. Hos de tysksindede viste sig en stor demoralisation. I stedet for at søge skolen skal tysksindede børn hos et par værtshusholdere have modtaget undervisning $\mathrm{i}$ oprørssangen.

Medens vi nu lader de tilbagevendte kirkevisitatorer, greven og provsten, foreløbig fungere i deres gamle embeder, skal vi se lidt på, hvordan det var gået med deres underordnede, navnlig præsterne i det blandede distrikt, da stormen kastede sig imod dem.

Lignende begivenheder som i Tønder, om end i mindre format, kunde man vel vente skulde være udspillede i Læk. Her sad af danske embedsmænd

1) Breve til Hjort fra Christine Johannsen ${ }^{24} / 4$ 1864, fra Albertine Sørensen ${ }^{11} / \mathrm{s} 1864$ og fra H. Feddersen ${ }^{21} / \mathrm{s} 1864$. 
de to præster J. A. Jacobsen som 1. kompastor og som 2. kompastor Andr. Christ. Riis-Lowzon, endvidere herredsfogden for Kær herred A. Th. Willemoes samt thingskriveren Chr. Holm. Da efterretningerne den 6. februar indlob om den danske hærs tilbagetog, kom de tysksindede $i$ den største bevægelse. Efterhånden opfyldtes byen af frisere, der svirede $i$ kroerne sammen med lederne af det slesvig-holstenske parti i Læk og omegn. I morkningen indtog de en truende holdning. Bevægelsen rettedes først mod pastor Riis-Lowzon, hvis hus om natten angrebes, uden at man dog fik døren sprængt. Han selv flygtede alene om natten uden at få det mindste med sig og kom om morgenen til Tønder. Senere indfandt hans kone og børn sig sammesteds efter i høj grad at være bleven generede og fortrædigede af den rå pøbel. Pastor Jacobsen synes man egentlig på tysk side forst at have tænkt på at beholde, men man må senere være kommen på andre tanker. Søndag eftermiddag kom en stor skare ned mod præstegården. Som ordfører havde de den tysksindede godsejer Funke på Fresenhavn (Læk sogn), og denne var på arme og bryst tæt behængt med slesvig-holstenske sløjfer og bånd. Til pastor Jacobsen holdt Funke følgende tale: "Wir wtinschen, Hr. Pastor, dass Sie nach Norden abreisen, wollen Sie das? Das ist nicht Ihre Person, sondern das von Ihnen repräsentirte Princip, welches wir los werden wollen; das Dänentum ist abgeschafft, und wir haben jetzt Schleswig-Holstein “. $\left.{ }^{1}\right)$ Da Jacobsen spurgte, med hvilken ret han stillede en sådan opfordring til ham, svarede han kun

1) Oversat: "Vi ønsker, IIr. pastor, at De rejser bort mod nord, vil De det? Det er ikke Deres person, men det af Dem reprasenterede princip, som vi vil være fri for; danskheden er afskaffet, og vi har nu Slesvig-Holsten«. 
med et truende fingerpeg på mængden udenfor. Jacobsens videre spørgsmål, om han kunde drage bort med kone og børn i fred og ro, besvarede Funke bekræftende, når han forlod byen den næste morgen tidlig. Straks derefter fik Jacobsen at vide, at Willemoes og Holm også var forviste fra byen, og de besluttede så at forlade den i fællesskab. Natten mellem søndag og mandag modtog Jacobsen en henvendelse fra et par beboere om at blive, men dette afslog han, da de pågældende ikke kunde indestå for, at han ingen personlig overlast vilde lide. Mandag morgen ved daggry forlod Hans Majestæt kongens embedsmænd Læk. Den følgende dag skete i Læk som i Tønder proklameringen af prætendenten. I Læk er det endda formentlig gået bedre med salmesangen end i Tønder, idet man i Læk fik forlokket den derværende degn til at lede sangen. Det skal endnu bemærkes, at ingen af de to fjernede præster, să vidt ses, gjorde forsøg på at vende tilbage. De må have anset det for håbløst. Straks i begyndelsen af marts nıåned udnævntes der en oprørsksindet præst.

Det mest tysksindede af Tonder provstis blandede sogne var utvivlsomt Klægsbøl, hvor Chr. Pram Gad sad som præst fra 1860 . Forskellige ting bragte denne på den tanke, at man troede, han efter Dannevirkestillingens rømning vilde flygte. I et møde af sogneforstanderskabet om eftermiddagen den 7. februar erklæerede han derfor for at forebygge misforståelser, at det var hans hensigt at forblive i embedet, så længe han kunde forsvare det for Gud og sin samvittighed. Herpå svarede man ham, hvorfor han ikke skulde kunne blive, han havde intet at frygte af dem, de vilde ikke gøre ham noget. Men til trods for disse forsikringer trængte om aftenen en pobelhob ind $i$ 
hans hus. Foruden af et par af sognets forlorne subjekter skal sværmen have bestået af "læredrenge, håndværkersvende, gadedrenge samt af frisere fra sydligere sogne, hvilke i forveien havde beruset sig i kroerne og der hentet mod til at udføre deres bedrifter". Anforerne melldelte, at prætendenten skulde proklameres næste clag, og at prasten derfor havde at være borte fra sognet inden $\mathrm{kl}$. 6 næste morgen. Da Gad spurgte, hvad der vilde ske, hvis han ikke drog bort, svaredes der med en trusel mod hans person, sværmen trængte ind på ham og brølede "Schleswig-Holstein meerumschlungen«, så det rungede $\mathbf{i}$ hele pastoratet. . Efter at have fảet nøglen til kirketårnet fjernede skaren sig for at stikke det slesvigholstenske flag ud fra tårnet, og der råbtes Hoch for „Friedrich der Achte«. Endnu et par timer kredsede pøbelen under vilde skrig om præstegården. Kl. 1 om natten drog Gad bort. Også degnen blev forjagen. Medens degnen senere vendte tilbage efter aftale med provst Hjort, kom Gad derimod ikke igen. Hjort vilde ganske vist også have ham tilbage, men brevet med denne anmodning nåede først Gad adskillig tid senere, og Gad troede da ikke, at han kunde holde sig dernede. Han undslog sig derfor for at komme. ${ }^{1}$ ) Da Hjort $i$ en bestemt anledning fik besog af et par af de oprørsksindede fra sognet, bebrejdede han dem alvorligt den tumultuariske måde, hvorpå de var gået frem, i stedet for roligt at afvente begivenhedernes gang, der nu syntes at gâ efter deres ønske. Men de svarede, at da de så længe havde levet under tryk, var det ikke til at undres over, at folket nu slog sig løs.

1) Se brev 6. marts 1864 fra Gad til Hjort. 
Efter Klægsbøl kom sikkert Karlum sogn med hensyn til tysksindethed. Her sad som sognepræst E. Th. Brask fra året 1856. Også han måtte vige, men dog først dagen efter den Klægsbøl præst. Om eftermiddagen den 8. februar samledes de fleste mandlige beboere i Karlum kro, og en slesvig-holstensk fane blev stukket ud af vinduet. En deputation på 6 mand afsendtes til præsten for i folkeviljens navn at byde ham rejse, da det skulde dokumenteres, at Karlum sogn ønskede og kun vilde have tysk. Brask anså det for unyttigt at gøre modstand og indvilligede $\mathrm{i}$ at drage bort. $\mathrm{Kl} .1 \mathrm{om}$ natten kom han sammen med sin kone kørende over til nabopræsten, O. F. H. Mynster, i Ladelund, og kl. 5 om morgenen tog de videre fulgt af Mynsters kone og 4 små børn. Brask tog til Ribe og skrev herfra til ministeriet om sin fordrivelse. Han havde i sandhed, skrev han, ikke stor lyst til længere at være præst i et sogn, hvor man havde opført sig sådan, men han vilde dog til enhver tid lyde sin regering. Den 15 . vovede han sig også tilbage til Tønder og afgav her den af civilkommissæren fordrede underkastelseserklæring, og den 16. tog han til Karlum. Han forefandt her sit husvæsen i stor uorden og klager bl. a. over, at tjenestefolkene $\mathbf{i}$ den forløbne uge havde brugt til husholdningen lige så meget, som der ellers brugtes $\mathbf{i}$ en måned. Efter sin hjemkomst fungerede han som sædvanligt, men under hans fraværelse havde den tysksindede degn på skoleinteressenternes forlangende forandret skolesproget til tysk. Trods Brasks og senere provstens opfordring til atter at indføre dansk, holdt degnen fast ved det tyske. Brask beretter, at degnen deltog i alle politiske møder og forsamlinger, og at han også - ligesom de fleste tysksindede i sognet - skal have 
haft prætendentens portræt i glas og ramme i sin stue. Brask selv behandledes efter sin hjemkomst med største kølighed af sognets store bønder. Man anbragte også et stort oprørsflag uden på kirken, og de danske flag på skibet i kirken erstattedes med slesvig-holstenske. De få velsindede beboere vovede ikke ved dagens lys at besøge præstegården, men listede sig dog stundom i aftenens mørke derop for at høre, hvordan det gik præstefolkene.

I Sønder-Løgum havde pastor I. Reimuth et stort. parti for sig, og ved en forsamling af sognemændene i kroen erklærede en stor mængde sig for at beholde ham. Efter fleres råd forlod han alligevel - det synes nærmest frivilligt - sognet $i$ omkring 8 dage for at gå af vejen for den første storm. Derefter vendte han tilbage og fungerede foreløbig uantastet. Degnen indførte tysk i overklassen.

I Brarup sogn var der vakance, i Humdrup var præsten tysksindet, og i Ubjærg forstod pastor Göttge $i$ hvert fald at bære kappen efter vinden. Her opretholdtes iøvrigt foreløbigt dansk skolesprog. I Medelby var pastor Christiansens forhold til menigheden et sådant, at der ikke kunde befrygtes uroligheder. Det fortælles dog, at oprørsfanen blev hængt ud af kirken, men den blev straks taget ned og slængt hen i den mands møddingpøl, der havde hængt den op. Pastor Christiansen skal på en dansk søndag have holdt tysk gudstjeneste, og lærerne skal enten have indført eller lovet mere tysk i skolerne. Såfremt dette nu har fundet sted, gik det imidlertid hurtigt tilbage i den gamle gænge. Den danske gudstjeneste besøgtes også fremdeles som sædvanligt.

Af de udpræget dansksindede præster i provstiets blandede sogne red alene pastor O. F. H. Mynster 
i Ladelund stormen af. Han var bleven ansat her i 1859, og der havde udviklet sig et særdeles venligt forhold mellem ham og menigheden. Sprogordningen føltes i Ladelund efterhånden så naturlig, at der i det sidste halvandet år før krigsudbruddet ingen ministeriallhandlinger forlangtes udførte på tysk. Krigsudbruddet og agitationerne forandrede dog naturligvis alt til det værre. Hvad der hjalp Mynster til at holde sig, var, mener han, at han havde sine konfirmander så vidt forberedte, at han ved at læse med dem hver dag kunde konfirmere dem med korteste frist. Han berammede nu konfirmationen til den 14. februar. Som ovenfor nævnt havde han ladet sin kone og sine små børn følge Brasks på deres bortrejse den 9. - på åbne vogne i snefog og vinterkulde. Efter familiens bortrejse følte han sig mere uafhængig, men også frygtelig alene - uden øvrighed og uden andre nabopræster i det blandede distrikt end Christiansen i Medelby. På tysksindedes råd til ham om at rejse svarede han imidlertid, at han forblev på sin plads, til han blev pilsket bort, og selv $i$ dette tilfælde var det muligt, at han gik tilbage igen. Den store anstødssten for sognets tysksindede var selvfølgelig kirkebønnen for Christian IX, men Mynster vilde ikke indlade sig på at lade denne falde bort. På konfirmationsdagen den 14. bad han den i kirken så højt, som han aldrig før havde gjort. Alt forblev ganske vist stille i kirken, men natten efter stenede man hans hus med store sten i 3-4 timer, slog mange ruder ind og plantede oprørsflaget på huset. Flaget lod han om morgenen tage ned og brænde. Da han ved en ligprædiken den 15 . begyndte at bede for kongen, kom lidenskaberne til udbrud. Der blev stærkt røre og snakken i kirken, og mændene mar- 
cherede under stærk trampen ud. Mynster holdt derpå op, afsluttede med fadervor og velsignelsen og bemærkede, da han indså det umulige $i$ at fortsætte sin virksomhed $i$ lovlig ånd og form, at hans arbejde nu var forbi. Han var nu bestemt pả at rejse bort. Da fik han hen mod aften meddelelse om, at kirkevisitatoriet var kommet tilbage, og at også præsterne Brask og Reimuth vilde vende hjem til deres embeder. Han underskrev derefter underkastelseserklæringen. Efter samråd med provsten bestemte han sig til fremtidig at udelade kirkebønnen for kongen og kongehuset, som iøvrigt.først af civilkomnissærerne afskaffedes ved en bestemmelse af 3. marts. Den følgende søndag vendte hans kone og børn hjem.

Om forholdene i Ladelund i tiden derefter skaI her endnu gøres et par bemærkninger. Efter Mynsters udsagn vedblev den danske gudstjeneste stadig at være den bedst besøgte. Det danske skolesprog var også hele tiden bleven opretholdt trods det pres, som de tysksindede havde forsøgt at lægge på lærerne. Nogen behagelighed for præsten at være forbleven på sin plads var det dog ikke. Om natten kastedes der ofte sten mod præstegården under vilde skrig, og man istemte: "Schleswig-Holstein stammverwandt, jag die Dänen aus das (!) Land!« Berusede folk kom henad natten, rev i dørene og råbte, at præsten skulde wheraus«. En pøbelsværm truede engang med at sætte ild på huset, præsten skulde bort: »wenn Sie die børn nikt tydsk læren vil«. Man slog ruder ud, og klager til herredsfogden om beskyttelse besvaredes overhovedet ikke eller med, at der ikke var noget at gøre ved den ting. Ofte måtte præstefolkene ligge med klæderne på om natten og ofte blive oppe. Naturligvis drillede man præsten med slesvig-hol- 
stenske flag, af hvilke man efterhånden i landsbyen fik anskaffet sig en halv snes stykker. Man undså sig endog ikke for på selve Langfredag at anbringe et par slesvig-holstenske flag ved indgangen til kirkegården, som præsten måtte gå igennem. At byens drenge lod det gå ud over præstens ældste knap 6årige dreng, hvem man kastede en sten $\mathbf{i}$ hovedet, er jo ikke til at undres over.

Det eneste af provstiets blandede sogne, der ikke hørte til Kær herred, var Avntoft i Viding herred. Præsten her var fra 1861 G. G. W. Berggreen, og som det fremgår af det følgende, synes han at have været afholdt af $\sin$ menighed. Den eneste danskdannede kollega, som han havde $\mathbf{i}$ herredet, var præsten i Nykirke F. C. H. Sodemann, der iøvrigt var født $i$ Rostock.) Sodemann fordreves natten mellem den 8. og 9. februar. Om aftenen den 8. februar samledes en skare frisere $i$ Avntoit kro i den hensigt at få Berggreen forllevet. Det påtænkte angreb afværgedes dog ved kromandens besindighed. Til den 9. sammenkaldte Berggreen et mode af sognekollegiet for at høre dets mening om sin stilling. Hvad han inden dette møle erfaretle, skulde ikke opmuntre ham til at holde ud i embedet. I kroen besvarede udensogns folk ytringer fra hans sognemænd om, at de ønskede at beholde deres præst, med meget djærve forsikringer om, at de nok skulde vise både sognet og præsten, at han skulde blive forjagen. Nybølleme, der $i$ det hele synes at have været ivrige ved optøjer og demonstrationer, vilde have hele viding herred "renset«, og pøbelen på Tønder gader udstødte trusler mod "den danske hund", der endnu sad i embedet i Avntoft. Om formidalagen den 9. drog store

1) Meddelelser om invasionen. 14 
skarer af frisere med vilde skrig og med den slesvigholstenske fane i spidsen forbi Avntoft præstegård. I kroen standsede de et øjeblik for at meddele, at det gjaldt præsten, når de vendte tilbage fra Tønder, hvorhen de drog for at proklamere Augustenborgeren. Ved middagstid afholdtes så sognekollegiets møde, hvor dog et medlem udeblev. De tilstedeværende erklærede, at de gerne beholdt præsten, og at dette sikkert også i det hele var sognets onske, men at de aldeles ikke så sig i stand til at sikre ham mod overlast fra andre sider. Det antydedes ganske vist, at adskillige af Avntofterne var rede til med magt at modsætte sig angreb på ham, men herom vilde Berggreen intet vide - af hensyn bl. a. til sognets gode forhold til nabosognene. Berggreen var dog imidlertid endnu bestemt på at blive, men da modtog han midt under modet et brev fra en til Mrgeltønder flygtet kollega, der bad hain på det mest indtrængende om uden at spilde et øjeblik at drage bort. Han læste dette brev højt for kollegiet, der nu også fandt det bedst, at han forelobigt veg. Han gik derpå til Møgeltønder. Om aftenen kom friserne som bebudet igen for at gaste ham, men da de fik at vide, at han var borte, drog de hujende forbi. En snes Avntoftere havde for resten beredt sig til at forsvare deres præst. I Møgeltonder forblev Berggreen derefter i nogle dage og deltog $i$ forhandlingerne med de andre der forsamlede danske embedsmænd. Han kunde imidlertid ikke gå ind på kirkevisitatorernes betragtning, at man måtte afgive den fordrede underkastelseserklæring. Søndag den 14. om aftenen vendte han tilbage til sit $\operatorname{sogn}$, men her krævede man nu, at kirkebonnen for kongen skulde bortfalde og ligeledes, at dansk prædiken skulde afskaffes. Da han ikke 
kunde føje menigheden heri og som sagt heller ikke vilde afgive den nævnte erklæring, drog han igen bort og tog til København. Degnen gjorde alting tysk. Provst Hjort synes at have været noget utilfreds med Berggreens adfærd. Han skriver i sin beretning, at han mener, Berggreen kunde have holdt sig, og anker over, at han drog bort uden meddelelse til kirkevisitatoriet. Noget efter ankomsten til København skrev Berggreen til Hjort, at han nu var villig til at venile tilbage og afgive den forlangte erklæring. Dagen efter dette brev - den 5. marts - afskedigedes han imidlertid af civilkommissærerne. Han konstitueredes nu i Nordborg, nen blev nogle måneder senele også afskediget fra dette embele og med 3 dages varsel udvist af hertugdønmet.

Som ovenfor bemarket spillede Nybullerne en betydelig rolle $i$ optojerne og demonstrationerne. Fra Nybøl forjoges også allerede den (i. februar on aftenen alle de clerværende danske embedsmænd. En påbudt levering af vogne til hæren synes her at have givet stødet til optøjerne. Nybøllerne var det ligeledes, der vist den 7. mishandletle og forjog den danske pastor P. Petersen i Dedsbøl. Man vilde hąve udleveret è Dannebrogsfane, og da præsten ikke kunde finde den, gav man sig til at mishandle ham. Dedsbøllerne kom ham dog til hjælp, og han slap bort, hvorefter pobelen molesterede huset. Han synes at have været den af provstiets præster, der led mest.

Mellem provstiets tyske og blandede sogne på den ene side og dets danske sogne på den anden side viste der sig selvfølgelig, som også provst Hjort betonede i sin beretning, en stærkt fremtrædende modsætning. Overalt, hvor det danske begyndte, fandt uvæsenet sin grænse. Var der end i nogle sogne en del 
urostiftere, vovede de dog ikke overfor den herskende danske stemning at sætte noget $i$ værk. Det kan således næunes om Hostrup sogn, at man udefra til dette sendte bud, at vilde sognet ikke selv jage præsten bort, skulde man nok sørge herfor. Men fra sognet svaredes, at med mindst 50 mand skulde man nok få bugt. I de mest bevægede dage lod man her gå nattevagt for straks at kunne kalde folk sammen. At der rorte sig en del tyske sympatier i sogne som Tinglev, Ravsted, Burkal og Abild, var vel kun at vente.

\section{Civilkommissærenes embedsafsættelser.}

Den første storm, den slesvig-holstenske kan man vel kalde den, havde, som det fremgår af det foregående, bevirket et betydeligt mandefald $i$ de danske embedsmænds rækker i Tonder provsti. Det skulde meget snart tynde yderligere ud iblandt dem, og for de tilbagevendte embedsmænds vedkommende var der nærmest kun tale om en galgenfrist. Den stadfæstelse i embederne og den lovede beskyttelse, der var udtalt i Wrangels cg Zedlitz' proklamationer, skulde vise sig at være tomt mundsvejr.

Preusserne begyndte, som rimeligt var, fra oven, med de overordnede embedsmænd i Tonder. Allerede den 17. februar modtog borgmesteren og politimesteren I. H. Holm sin afsked; nogen som helst begrundelse for denne meddeltes overhovedet ikke. Han fik som efterfølger en mand ved navi Bleicken, der var født på Sild, og som i $1849-50$ havde været sekretær hos den.oprorske amtmand Hansen $i$ Tønder amt. Ved denne som ved så mange andre af embedsbesattelserne gjorde preusserne brug af de folk, der 
havde spillet en rolle under oproret og efter dette var dragne bort eller afsatte som embedsmænd af den danske regering. Efter Holm fulgte herredsfogden for Tønder og Højer herreder, C. A. Kiær, der afskedigedes den 24. februar. Så kom raden til selve amtmanden, grev Brockenhuus-Schack, som fik sin afsked den 12. marts med den begrundelse, at han ikke ansås for egnet til at fremme civilkommissarernes hensigter. Efterfølgeren blev overappellationsretsråd i Kiel, etatsraad C. O. M. de Fontenay, der havde aflagt ed til Augustenborgeren. Herefter var provstens stilling naturligvis i længden uholdbar. Fontenay sogte at få ham til frivilligt at anmode om sin afsked. Det vilde Hjort dog ikke, men allerede den 22. marts modtog han entledigelse som provst og llovedpræst, og Carstens konstitueredes i begge embederne. Langfredag aften den 25. forlod Hjort med sin familie Tønder. Der vistes dem ved afrejsen megen deltagelse fra den danske menighed, og der havde samlet sig ikke få for at sige dem farvel.

Om forholdenes udvikling i Tønder by, medens Hjort endnu sad som provst, og i den forste tid efter hans afrejse skal endnu gøres et par spredte bemærkninger. Det endte med, at så godt som alt blev tysk. Endnu medens Hjort var provst, foretoges der efter ordre fra civilkommissærerne en afstemning, om man onskede tysk eller dansk skolesprog. De danske besluttede at afholde sig fra afstemningen. Om denne holdning var det lettest at opnå enighed, og der synes $i$ det hele ikke at have været for meget mod hos de dansksindede. Enkelte danske småfolk skræmtes til at underskrive for tysk. Et andragende om tysk skolesprog blev derefter indgivet til civilkommissærerne og af disse billiget ved forordning af 
30. april. Det tyske skolesprog havde naturligvis fjernelsen af et par danske lærere til folge. Ligeledes medens Hort endnu var provst lykkedes det Carstens at fả den danske realskole i byen og det private lanske pigeinstitut lukkede - i anledning af en påstatet formfejl i sin tid ved deres oprettelse. Bestyreren for realskolen søgte senere civilkommissærerne om skolens genåbning, men fik afslag på grund af sin nationaldanske holdning. Bade han og bestyrerinden for pigeinstituttet gav så foreløbig privattimer til en del af deres elever.')

Som nævit var Carstens kun bleven konstitueret i Hjorts embeder. Allerede 11. april udnæuntes $i$ hans stel C. A. Valentiner, der tidligere havde været præst i hertugdommet, men 1850 var afskediget af bestyrelseskommissionen og var gået til Tyskland. Foruden udnævnelsen til provst og hovedpræst fik han ogsả lidit senere det hverv at reorganisere hertugdømmets seminarier. ${ }^{2}$ ) Han holdt sin tiltrædelsespradiken sondag den 24. april og begyndte med at fortælle, at han bragte sit kære slesvigske fædreland det offer for et halvt ăr at forlade sin menighed for at gengive Tønder kirke og skoler og seminariet deres fra gamle dage tilhørende rettigheder, nemlig det tyske sprog.") Om skolernes overgang til tysk er ovenfor talt. For kirkesproget kom der en forordning af 24. juni, der indførte udelukkende tysk formiddagsgudstjeneste og afvekslende dansk og tysk eftermiddagsgudstjeneste. Det genåbnede seminarium fik en dansk og en tysk klasse. Valentiner blev som

1) F. F. Ulrich til Hjort $14 / 41864$.

2) Meddelelser om invasionen. 52 .

3) Christine Johannsen til Hjort $24 /$ 1864. H. Feddersen tit $\mathrm{Hjort}^{5 / 5} 1864$. 
sagt kun et halvt års tid. Den 28. september udnæuntes Carstens til provst og hovedpræst.

Efter at både grev Brockenhuus-Schack og provst Hjort var afskedigede, var det at vente, at heller ikke de tre tilbageværende dansksindede præster $\mathbf{i}$ det blandede distrikt, Reimuth i Sønder-Løgum, Brask i Karlum og Mynster i Ladelund, ret længe vilde undgå samme skæbne. Måden, hvorpå de fjernedes, var i stort set ens. De nye kirkevisitatorer, de Fontenay ox Carstens, kom til det pågældende sogns kro og lod afholde afstemning om, hvorvidt beboerne onskede dansk eller tysk kirke- og skolesprog. Disse afstemninger faldt naturligvis ganske overvejende ud til fordel for tysk. Derefter tog Carstens præsten afsides for mell søde ord at bevæge ham til frivillig at tage sin afsked - det mislykkedes dog alle tre steder - og imedens søgte amtmanden at få beboerne til at fremkomme med klager over præsten. Ikke tale om, at sådanne klager senere meddeltes præsten, for at han kunde forsvare sig. Et rent komediespil var det hele. Så medilelte civilkommissærerne præsten afsked under henvisning til den afholdte "specialvisitation", hvorved det var befunden, at præsten ikke var tysk tilstrækkelig magtig, og at han ikke stod $i$ det rette forhold til sin menighed. Reimuth afskedigedes den 21. april, Mynster den 2. maj og Brask den 4. Da Brask i beretningen om sin afsked har anfort ordlyden af rivilkommissærernes skrivelse, tilføjer han: "Hertil er intet at bemærke undtagen, at det er åbenbar usandhed, at der er afholdt nogen specialvisitation i Karlum i indeværende år. Det samme kunde de andre to med sandhed have bemærket.

De foretagne sogneafstemninger $i$ det blandede 
distrikt medførte indforelse af tysk skolesprog og af omtrent udelukkende tysk kirkesprog. På ordningens enkeltheder skal jeg her ikke gå ind. $\left.{ }^{1}\right)$ Afstemningerne var selvfolgelig ikke "frie«, da tysksindede storbønder terroriserede småfolk og håndværkere, og det var klart, hvad resultat kirkevisitatorerne vilde have ud af afstemningerne. I Ladelund udbrod Carstens "Schön«, når beboerne fornægtede deres modersmål og satte tysk ved rubrikkerne on kirke-, skole- og hussprog. Med største og unægtelig ikke uberettiget forargelse omtales det af de danske præster, hvordan beboerne løj og erklærede tysk for deres sprog, skønt de slet ikke kunde tale det. Da et par bønder i Sønder-Løgum overfor amtmanden skulde fremfore klagerne over præsten pả tysk, gik det helt i stă for dem, og en høker, der havde lært handel - og tysk - i Flensborg, måtte træde hjælpende til. Her i sonder-Løgum fik forøvrigt en ny lærer, der var en ivrig agitator, stiftet en "Concordia-Verein«, hvis medlemmer forpligtede sig til kun at tale tysk og til at erlægge mulkt for hvert dansk ord, som de sagde. Den præst, der efter Mynsters og Brasks afsked bestyrede Ladelund og Karlum, vilde i Karlum have lavet en lignende forening. En bonde, som han henvendte sig til herom, svarede imidlertid: "Nej, det gåer ikke, for der er ingen af os, der kan snakke tydsk “.') Men til trods herfor og til trods for, hvad der kan indvendes mod afstemningerne, kan man vel nok sige, at flertallet eller $i$ hvert fald de magthavende og indflydelsesrige $i$ de blandede sogne ikke vilde beholde den danske præst og skolelærer: "wenn Sie die born nikt tydsk læren vil".

\footnotetext{
1) De pägaldende bestemmelser findes i Meddelelser om invasionen.

2) (). F. II. Mynster til Hjort $2 \% 1864$.
} 
I løbet af ounkring et fjerdingår var det 'således lykkedes at få fjernet alle de i provstiets blandede sogne siddende dansksindede præster - jeg ser bort fra Christiansen, Medelby -, selv om man havde måttet tage det i to omgange. På omtrent samme tid havde man fået genindfort $\mathrm{i}$ det store og hele den sprogordning, der i disse sogne bestod før 1848. Også et par dansksindede præster i rent tyske sogne var blevne fjernede. For provstiets danske sogne skete der derimod foreløbig ikke så store forandringer, og grundene hertil var vel flere. Det måtte formentlig være noget betænkeligt for de nye magthavere at begynde med en altfor voldsom oprydning blandt de danske præster i Nordslesvig, thi hvorfra skulde man i en hast fả erstatning for disse? For de danske sogne i Tønder provsti må det endvidere bemærkes, at i 5 af de 13 sogne sad der præster fra tiden før 1848. Flere af disse var dog vist tysksindede og kunde altså gøre god fyldest under det nye regimente. Af præsterne i de 8 tilbageværende sogne skulde 3 udpræget danske præster modtage deres afsked af civilkommissærerne, nemlig Johs. Kok i Burkal, M. Mørch i Hostrup og F. H. Lützhøft i Byllerup.

Som det forste offer faldt Johs. Kok. Fra sognet blev der af tysksindede beboere indgivet forskellige klager over ham, og han kaldtes da ind til Tønder den 11. april for at forsvare sig overfor kirkevisitatoriet.') Det blev sagt, at mange i menigheden på grund af hans afgjort danske holdning ikke kunde føle sig opbygget af hans prædikevirksomhed. Kok indrømmede dette, men påstod, at en mand med mod-

1) Den fólgende fremstilling bygger på et brev fra F. F. Ulrich til Hjort $14 /$, 1864. Ulrich har sin beretning fra kok. 
satte anskuelser vilde have tifold storre vanskelighed ved at virke i Burkal sogn til opbyggelse. Man drøftede derefter forskellige af Koks danske udtalelser, bl. a. $\mathbf{i}$ indledningen til hans bog "Det danske folkesprog«, men Kok mente ikke, at de vedkom hans underkastelseserklæring. I kollisionstilfælde vilde han søge sin afsked. Amtmanden spurgte, om han da ikke nu vilde søge denne, men det vilde han ikke. Senere kom Carstens med en bemærkning om, at Kok altid havde været konsekvent $i$ sit standpunkt, og at han, Carstens, selv også havde været dette. Den sidste betragtning kunde Kok dog ikke gå ind på, og da der blev talt om eden til Christian IX, som også Carstens havde aflagt, og denne mente, at det kom an på fortolkningen, udtalte Kok, at en ed var en ed, og enten brod man den, eller holdt man den, anden fortolkning kendte han ikke. ) I den over forhandlingen optagne protokol indfortes, at Kok ikke med »inderlig samstemning " kunde medvirke til civilkommissærernes opgave. Med denne begrundelse modtog han noget senere den 29. april sin afsked.

Først godt tre måneder senere - den 8. august afskedigedes Mørch og Lützhøft, forøvigt samtidig med en hel række andre nordslesvigske enıbedsmænd. Efter Londonkonferencens sprængning og krigens genudbrud havde civilkommissærerne udstedt et cirkulære om, at man måtte opfordre de emledsmænd, der endnu i deres samvittighed følte sig bundne overfor den danske regering, til enten at lose dette forhold eller nedlægge deres embeder.') I henhold til dette cirkulære forelagdes der den 15. juli de to nævnte præster en erklæring, som de ikke mente

1) Til denne drøftelse sigter en anmarkning i Meddelelser om invasionen. 22.

2) Meddelelser om invasionen. $21 \mathrm{f}$. 
at kunne underskrive: Herefter modtog de som nævnt deres afsked. For Mørchs vedkommende havde man forøvrigt tidligere søgt at udvirke hans afsked, uden at det dog var bleven til noget. Man havde fået tilvejebragt klager fra tysksindede beboere i Hostrup sogn, og en af de første dage i juni var han bleven indkaldt på Tønder amtshus..) Her var det bleven ham foreholdt, at han med sit danske sindelag ikke kunde fremme civilkommissærernes hensigter og ojemed. Men han havde havdet, at sindelaget var dem uvedkommende. Derpå var det anført imod ham, at han gjorde småfolk i sognet modlose ved at fortælle, at de danske snart kom, og at han kaldte de allierede tropper for fjender. Hertil havde han svaret, at han fortalte både indholdet af danske og tyske aviser, men aldrig gjorde folk modlose. Af hans sogn var 50-60 mand i den danske hær, og de, som disse kæmpede imod, måtte både $i$ hans og sognets øjne betragtes som fjender.

For at forebygge Morchs afskedigelse var der kort efter denne forhandling $i$ sognet bleven samlet underskrifter på et andragende til rivilkommissærerne om at beholde ham. Kun nogle ganske få af sognets beboere skal have undladt at underskrive dette andragende.

Også et andragende fra Bylderup sogn til civilkommissærerne om at beholde pastor Lützhøft fik det ganske overvejende antal af beboernes underskrifter.") Men det sluttelige resultat var jo i begge tilfælde det samme: de dansksindede præsters afskedigelse.

1) Det følgende bygger pá F. F. Ulrichs brev til Hjort $3.4 \% 1864$.

2) Meddelelser on invasionen. 72 . 
I det i begyndelsen af denne skildring omtalte brev af Regenburg havde denne skrevet: "Gid vi kun alle må have den bevidsthed at have gjort vor pligt og intet at have forsømt «. Det foregående viser dog vistnok, at dette onske i nogen grad opfyldtes af de danske embedsmænd i Tønder provsti, der stilledes først overfor det slesvig-holstenske røre og senere overfor civilkommissærernes regimente. Blandt de danske embedsmænd fandtes der både mod og mands hjerte og viljen til ikke uden modstand at vige pladsen for de fremmede $i$ mdet ældgamle danske land Sønderjylland«. Efterhånden som den ene efter den anden måtte vige, voksede dog naturligvis ensomhedsfølelsen blandt de tilbageblevne. Flere har vistnok også ligefrem længtes efter at få deres afsked og komme bort fra de utålelige tilstande. Men frivilligt veg de ikke. Og efter at embedsmændenes modstand mod den fremmede okkupation var brudt, stødte denne på et mere holdbart og varigt bolværk: selve den dansksindede befolkning. I et længere brev fra begyndelsen af juni 1864 havde fysikus Ulrich overfor Hjort givet en skildring af civilkommissærernes oprydning blandt embedsmændene, af det augustenborgske partis agitationer, af den danskskrevne, men tysksindede "Nordslesvigske tidende«s "sammensurium af logn og ondskab« $\mathrm{m}$. $\mathrm{m}$. "Se her, skrev han, en samling af småtræk på den skamløse vold og undertrykkelse sigtende til at denationalisere denne stakkels landsdel og odelægge enhver gnist af troskab og fædrelandskærlighed«. Jyderne led vel en del, fortsatte han, men det var dog mest i materiel henseende; det åndelige tryk havde de fælles med alle danske. Men sønderjyden led måske noget mindre materielt, men til gengæld arbejdedes der på 
at nødelægge ham moralsk, som menneske og statsborger $\mathrm{i}$ bund og grund. Hvad skal dog enden blive på dette.... «.

Fysikus Ulrich eller de andre danske embedsmænd i Tønder provsti, der i 1864 blev tvungne til at forlade deres gerning, skulde det ikke blive beskåret at se enden på det styre, der tog sin begyndelse med deres fordrivelse. Men tilsigtede dette styre end, som Ulrich skrev, at odelagge hos sønderjyden enhver gnist af troskab imod det gamle fædreland og kærlighed til dette, så skulde det dog her ikke have held med sig. Snarest voksede gnisterne, og de samledes til en varmende lue, der slog op i begejstring, da langt om længe udlændighedens time var omme. 